JBL 122/1 (2003) 23-52

\title{
COMPOSITRY AND CREATIVITY IN 2 SAMUEL 21:1-14
}

\author{
SIMEON CHAVEL \\ mssimi@pluto.huji.ac.il \\ The Hebrew University, Jerusalem, Israel
}

Despite a cluster of contrary indications, scholars have routinely interpreted the story of the three-year famine in 2 Sam 21:1-14 as an internally consistent, homogeneous narrative. ${ }^{1}$ This perception of the story may derive in part from its place as a link in 2 Sam 21-24, the chain of chapters closing the book of Samuel. Since Julius Wellhausen noted the palistrophe in chs. 21-24 over a century ago, this appendix compiled from disparate elements has tended to invite several kinds of literary approaches: structural analysis concerned primarily with its organization; interest in the lemmatic and thematic links governing its different parts; and a broader redactional view that seeks its meaning within the wider frameworks of the Succession Narrative, 2 Samuel, the complete book of Samuel, and the Deuteronomistic History. ${ }^{2}$ At least with regard to the Gibeonite episode, the focus on the literary shape and function of the

Thanks to Isaac Chavel, Baruch Schwartz, Michael Segal, and the JBL critical readers for their helpful comments. Translations are mine except where otherwise attributed.

${ }^{1}$ Survey the standard introductions and commentaries, for example, Carl Steuernagel, Lehrbuch der Einleitung in das Alte Testament (Tübingen: Mohr-Siebeck, 1912), 311, 326-27, 334-36. Only three attempts have been made to divide the story into sources; see below, nn. 5 and 31.

2 Julius Wellhausen, Die Composition des Hexateuchs und der historischen Bucher des Alten Testaments (3d ed.; Berlin: Georg Reimer, 1899), 260-61; Karl Budde, Die Bücher Samuel (KHAT; Tübingen/Leipzig: Mohr-Siebeck, 1902), xi, 304; Peter J. Kearney, "The Role of the Gibeonites in the Deuteronomistic History," CBQ 35 (1973): 1-19; Meir Steinberg, The Poetics of Biblical Narrative: Ideological Literature and the Drama of Reading (Bloomington: Indiana University Press, 1987), 40-42; Walter Brueggemann, "2 Samuel 21-24: An Appendix of Deconstruction?" CBQ 50 (1988): 383-97; Robert Polzin, David and the Deuteronomist: A Literary Study of the Deuteronomic History, part 3, 2 Samuel (Bloomington/Indianapolis: Indiana University Press, 1993), 202-14; Hans J. Stoebe Das zweite Buch Samuelis (KAT: Gütersloh: Mohn, 1994), 36-38, who argues well that a single editor compiled and ordered the entire appendix (p. 38).

23

This article was published in $J B L 122 / 1$ (2003) 23-52, copyright (C 2003 by the Society of Biblical Literature. To purchase copies of this issue or to subscribe to JBL, please contact SBL Customer Service by phone at 877-725-3334 [toll-free in North America] or 802-864-6185, by fax at 802-864-7626, or visit the online SBL Store at www.sbl-site.org. 
appendix as a whole seems to have distracted scholars somewhat from the task of an internal literary analysis. ${ }^{3}$

Other studies, whether seeking literary, historical, or cultic significance in the story, by and large fall into one of two categories. Either they attempt to locate the episode as a complete unit within some broader context, such as the historical role played by Gibeon in ancient Israel, or they concentrate on an obscure matter within it, specifically, the manner and meaning of the deaths of the seven Saulides and the significance of Rizpah's actions. ${ }^{4}$ Of course, such a

${ }^{3}$ Jan Fokkelman has in fact dissected 2 Sam 21:1-14 in his exhaustive structuralist manner, but having postulated the homogeneous character of the piece and the sufficiency of the MT as a matter of interpretive principle, he did not venture beyond the confines of synchronic analysis, which on occasion compelled him to scale the heights of hermeneutic ingenuity rather than delve into a diachronic analysis when faced with incongruity (Narrative Art and Poetry in the Books of Samuel, Volume 3, Throne and City [II Sam. 2-8 \& 21-24] [Assen/Maastricht: Van Gorcum, 1990], 271-92). See the brief but pointed methodological criticism in Jonathan Z. Smith, "Religion Up and Down, Out and In," in Sacred Time, Sacred Place: Archaeology and the Religion of Israel (ed. B. M. Gittlen; Winona Lake, IN: Eisenbrauns, 2002), 3-10, at 5.

${ }^{4}$ Henri Cazelles, "David's Monarchy and the Gibeonite Claim," PEQ 87 (1955): 165-75; Arvid S. Kapelrud, "King and Fertility: A Discussion of II Sam 21:1-14," NTT 56 (1955): 113-22 (cited here from the republished version in idem, God and His Friends in the Old Testament [Oslo: Universitetsforlaget, 1979], 41-50); Abraham Malamat, "Doctrines of Causality in Biblical and Hittite Historiography: A Parallel," VT 5 (1955): 1-12; Frank C. Fensham, "A Few Aspects of Legal Practices in Samuel in Comparison with Legal Material from the Ancient Near East," in Proceedings of the Third Meeting of Die Oud-Testamentliese Werkgemeenskap in Suid-Afrika (Pretoria: Aurora Drukpers, 1960), 19-27; idem, "Common Trends in Curses of Near Eastern Treaties and Kudurru-Inscriptions Compared with Maledictions of Amos and Isaiah,” ZAW 75 (1963): 155-75; idem, "The Treaty Between Israel and the Gibeonites," BA 27, no. 3 (1964): 96-100; Menahem Haran, "The Gibeonites, the Nethinim, and the Sons of Solomon's Servants," VT 11 (1961): 159-69; Jacob Liver, "The Literary History of Joshua IX," JSS 8 (1963): 227-43; Joseph Blenkinsopp, "Are There Traces of the Gibeonite Covenant in Deuteronomy?" CBQ 28 (1966): 207-19; idem, "Kiriath-Jearim and the Ark," JBL 88 (1969): 143-56; idem, Gibeon and Israel: The Role of Gibeon and the Gibeonites in the Political and Religious History of Early Israel (Cambridge: Cambridge University Press, 1972; reviewed by Moshe Weinfeld in IEJ 26 [1976]: 60-64); Blenkinsopp, "Did Saul Make Gibeon His Capital?" VT 24 (1974): 1-7: Robert Polzin, "HWQY` and Covenantal Institutions in Early Israel," HTR 62 (1969): 227-40; Baruch Halpern, "Gibeon: Israelite Diplomacy in the Conquest Era," CBQ 37 (1975): 303-16; Niek Poulssen, “An Hour with Rispah: Some Reflections on II Sam. 21,10," in Von Kanaan bis Kerala: Festschrift für Prof. Mag. Dr. Dr. J.P.M. van der Ploeg O.P. zur Vollendung des siebsigsten Lebensjahres am 4. Juli 1979: überreicht von Kollegen, Freunden und Schülern (ed. W. C. Delsman et al.; AOAT 211; Neukirchenen-Vluyn: Neukirchener Verlag, 1982), 185-211; Moshe Weinfeld, "Zion and Jerusalem as Religious and Political Capital: Ideology and Utopia," in The Poet and the Historian: Essays in Literary and Historical Biblical Criticism (ed. R. E. Friedman; HSS 26; Chico, CA: Scholars Press, 1983), 75-115; Ze'ev Weisman, "Legal Aspects of David's Involvement in the Blood-Vengeance of the Gibeonites" (in Hebrew), Zion 54 (1989): 149-60. Two illuminating articles on postbiblical interpretation of the pericope include Stanley D. Walters, "Childless Michal, Mother of Five," in The Tablet and the Scroll: Near Eastern Studies in Honor of William W. Hallo (ed. M. E. Cohen et al.; Bethesda, MD: CDL, 1993), 290-96; and Christopher Begg, "The Execution of the Saulides According to Josephus," Sefarad 56 (1996): 3-17.

This article was published in JBL 122/1 (2003) 23-52, copyright $(2003$ by the Society of Biblical Literature. To purchase copies of this issue or to subscribe to JBL, please contact SBL Customer Service by phone at 877-725-3334 [toll-free in North America] or 802-864-6185, by fax at 802-864-7626, or visit the online SBL Store at www.sbl-site.org. 
thumbnail sketch cannot do justice to the studies available, several of which have joined many interests under one rubric to yield a rich mine of analyses and ideas. However, they do all share in having failed to execute a careful literarycritical analysis, which, it turns out, could have led to the edited quality of the text. Two studies have in fact divided the text into sources, but not on the basis of defined, reusable criteria, on something beyond mere intuition. ${ }^{5}$

In one of the clearest, most comprehensive, yet most concise pieces available on identifying sources, Richard Friedman provides a detailed list of ten such criteria: doublets, terminology, contradictions, consistent characteristics of each group of texts, narrative flow, historical referents, linguistic classification, identifiable relationships among sources, references in other biblical books, and marks of editorial work. ${ }^{6}$ After applying them to the Pentatuech, he concludes compellingly:

The strength of the identification of the four major sources of the Torah is not any single one of the categories enumerated. ... Rather it is the convergence of all of these bodies of evidence that is the most powerful argument for this view of the Pentateuch (Friedman's italics). ${ }^{7}$

Werner Schmidt offers a more distilled programmatic outline for scholarly analysis of biblical texts:

a) analysis of the text for possible literary unevenness or tension;

b) alignment of the textual components obtained into the most likely story or plot lines, namely, not into fragments, which could not have existed independently;

c) comparison with the immediate and farther contexts and, with that, fitting them into a broader flow;

d) interpretation of the final form of the text. ${ }^{8}$

The investigation below of 2 Sam 21:1-14 will take its literary-critical cues specifically from disjunctures in both grammar and syntax, on one hand, and narrative flow, on the other. It will follow diction and theme, enlisting the often

\footnotetext{
${ }^{5}$ Serge Frolov and Vladimir Orel divided the story into two different sources, vv. 1-9 and 1014, with the respective attributions to $\mathrm{J}$ and $\mathrm{E}$ basically depending on the use of the name Elohim in v. 14b ("Rizpah on the Rock: Notes on 2 Sam. 21:1-14," ВeO 37 [1995]: 145-54, at 146). The effort, though, fails from several critical angles. Suffice it here to point out, as Budde already intimated long before, that v. 1 requires God's propitiation in v. 14b for its conclusion (Die Bücher Samuel, 309). This very interdependence led to Pesah Orion's proposal that vv. 1 and 14b once comprised an originally discrete and complete story_famine strikes; David beseeches YHWH; YHWH yieldswhich a later author used as a ready-made frame for the story he would insert ("A Note to 2 Sam 21:1-14" (in Hebrew), Bet Mikra 9 [1964]: 123-26, esp. 123-24). But Menahem Ben-yashar refuted Orion's arguments roundly ("A Study of the Pericope of Rizpah Daughter of Aiah" (in Hebrew), Bet Mikra 36 [1991]: 56-64). On a third, essentially acceptable division, see n. 31 below.

${ }^{6}$ Richard E. Friedman, “Torah (Pentateuch)," ABD 6:605-22.

7 Ibid., 618.

${ }^{8}$ Werner H. Schmidt, "Plädoyer für die Quellenscheidung,” BZ 32 (1988): 1-14, at 2.
}

This article was published in JBL 122/1 (2003) 23-52, copyright ( $\odot 2003$ by the Society of Biblical Literature. To purchase copies of this issue or to subscribe to JBL, please contact SBL Customer Service by phone at 877-725-3334 [toll-free in North America] or 802-864-6185, by fax at 802-864-7626, or visit the online SBL Store at www.sbl-site.org. 
untapped resource of textual criticism, to establish two independent threads (section I), then relate each one to the larger book of Samuel (sections II-IV). ${ }^{9}$ Finally, it will assess how intertwining the two threads has had an impact on each one of them, from a variety of standpoints (section $\mathrm{V}$ ).

This analysis has relevance for understanding the methods by which ancient editors brought together multiple textual sources and for evaluating the emergent product. In this case, by merely splicing together literary sources, the editor enhanced the human dimension guiding the story's flow and likewise deepened the story's broader political and theological messages.

Literary-critical analysis begins by following the narrative thread until it seems to fray or tangle. According to the flow of the narrative in 2 Sam 21:1-14, a string of three consecutive years racked by famine results from the unavenged bloodguilt of Saul and his household and their unabsolved violation of the vow Israel had previously made to the Gibeonites. In his overzealous bid to establish Israel's complete possession of its land, the narrator explains analeptically, Saul had wrongfully attempted to annihilate the Gibeonites. ${ }^{10}$ In doing so, he violated the oath taken before YHWH to preserve them in Israel's midst (see Josh 9:3-27). ${ }^{11}$ To redeem this bloodguilt and bring salvation to YHWH's land

${ }^{9}$ On the intersection of literary and textual criticisms, see the theoretical comments in Shemaryahu Talmon, "The Textual Study of the Bible: A New Outlook," in Qumran and the History of the Biblical Text (ed. Frank M. Cross, Jr., and Shemaryahu Talmon; Cambridge, MA: Harvard University Press, 1975), 321-400, at 327-32, and their application in Empirical Models for Biblical Criticism (ed. J. H. Tigay; Philadelphia: University of Pennsylvania Press, 1985) in the following essays: Jeffrey H. Tigay, "Conflation as a Redactional Technique," 53-95; Alexander Rofé, "Joshua 20: Historico-Literary Criticism Illustrated," 131-47; Emanuel Tov, "The Literary History of the Book of Jeremiah in the Light of Its Textual History," 211-37.

${ }^{10}$ Scholars all advocate emending the MT על שאול ועל ביתה דמים to אל שאול ואל בית הדמים

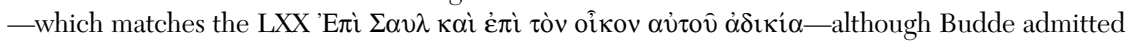
its "confused wording" and felt constrained to rewrite it (Die Bücher Samuel, 306). "The pronoun could not in a case like the present be dispensed with," Samuel R. Driver explained about the MT, troubled it seems by the elliptical style of the appositive clause: Which house? (Notes on the Hebrew Text and the Topography of the Books of Samuel [2d ed.; Oxford: Clarendon, 1960, 1963], 349). Recall, however, the notoriously abrupt and cryptic nature of oracular material, for instance, the much more ambiguous oracle in Judg 18:6 and the puzzling one in $2 \mathrm{Kgs}$ 8:10. In the words of John Dryden, "He speaks like the Oracles to puzzle the world" (cited in The Compact Edition of the Oxford English Dictionary: Complete Text Reproduced Micrographically [2 vols.; [U.S.A.]: Oxford University Press, 1971, repr. 1981], 2:2, 681). For that matter, the clarification "because he put Gibeonites to death" looks like the narrator's gloss (which is not to say an interpolation) rather than the oracle's own self-amplification.

${ }^{11}$ From the parenthetical style of the flashback in v. $2 b$, the awkward way it interrupts David's speech, and what appears to be a repetitive resumption in vv. 2-3 ("The king summoned

This article was published in JBL 122/1 (2003) 23-52, copyright @ 2003 by the Society of Biblical Literature. To purchase copies of this issue or to subscribe to JBL, please contact SBL Customer Service by phone at 877-725-3334 [toll-free in North America] or 802-864-6185, by fax at 802-864-7626, or visit the online SBL Store at www.sbl-site.org. 
and sustenance to his people, David agrees to the Gibeonites' demand-made after they subtly ascertained his frame of mind-that he turn over to them seven of Saul's heirs for impalement. ${ }^{12}$ David takes two sons from Rizpah, Saul's former concubine (2 Sam 3:7), and five grandsons from one of his daughters,

the Gibeonites and said to them ... David said to the Gibeonites"), many scholars have inferred the presence of an interpolation meant to link the story to Josh 9 (e.g., Henry P. Smith, A Critical and Exegetical Commentary on the Books of Samuel [ICC: Edinburgh: T \& T Clark, 1899, repr., 1969], 374). Though made with a different aim, Menahem Haran's point that the oracle specifies only Saul's bloodguilt, not his violation of the oath, could add support ("The Impaling of the Sons of Saul by the Gibeonites" (in Hebrew), in Studies in the Book of Samuel [2 vols.; ed. B. Z. Luriah; Jerusalem, 1962], 1:249-79, at 274). In addition, the Gibeonites negotiating with David themselves fail to mention Saul's violation of an oath. (A reference to the vow in the number of sons, seven, because of its sacred nature and also through assonance: שבעה/שבועה [Eng. seven/asseveration]so Yehuda Kil, 2 Samuel (Da'at Mikra; Jerusalem: Mosad Harav Kook, 1981), 503; and Polzin, David and the Deuteronomist, 209—seems far-fetched.)

However, v. 2b identifies the Gibeonites as Amorites, not as the Hivites of Josh 9:7 (which discrepancy the midrash harmonized cleverly with a bilingual pun in $y$. Qid. 4.1, 65c [bottom]; Num. Rab. \$8.4). It refers neither to Joshua nor to the chieftains, and it mentions none of the terms of the covenant. Indeed, not one lemma has an identifiable counterpart in Josh 9, and the description of the Israelites taking an oath actually contradicts Josh 9:14-18. These discrepancies imply that v. $2 \mathrm{~b}$ does not refer to the text of Josh 9, making it more likely that it preserves an authentic version of the tradition, which the author used in his composition, not a derived and interpolated reference. As to the repetitive resumption in vv. 2-3, it does not necessarily mark an interpolation into the preexisting text, but may indicate, rather, that the author composed the text from originally discrete materials (so Haran, "Impaling," 278). From the synchronic point of view of poetics, note the similar technique of analepsis delaying the main action in vv. 12-13a (against the harsh judgment Frolov and Orel passed rather glibly on the "gloss" as "clumsy" ["Rizpah on the Rock," 152]). Moreover, the recurring language in vv. 2-3 probably does not even constitute a repetitive resumption: ויאמר אליהם in v. 2a may refer to the act of speaking ("he told them") rather than introduce the contents of that speech ("he said ..."); compare Gen 4:8; Exod 19:25; 2 Sam 23:3; Ps 4:5; and Esth 1:18. Finally, the particular sacral aura permeating this episode radiates from something more than Saul's murder of Gibeonites, namely, his violation of the oath, which, as Malamat argued ("Doctrines of Causality," 9), makes v. 2 b necessary to the story's internal logic (see further below, nn. 43-44).

12 Jan Fokkelman notes the retributive ratio of seven to one in Ps 79:12 and Gen 4:15 as well (Narrative Art in Genesis: Specimens of Stylistic and Structural Analysis [Assen/Amsterdam: Van Gorcum, 1975], 39 n. 48).

Impalement may include broken or dislocated limbs (Stoebe, Das zweite Buch Samuelis, 454, v. 6 n. e). In traditional sources, see b. Sanh. 34b-35a; Rashi, Lev 19:28; Radak, Rabbi Davidis Kimchi Radicum liber sive Hebraeum bibliorum lexicon (in Hebrew; ed. Jo. H. R. Biesenthal and F. Lebrecht; Berlin, 1847; repr., Jerusalem, 1967), col. 295, p. 148. For modern treatments, see HAL 2:412; Wilhelm Gesenius, Hebräisches und Aramäisches Handwörterbuch über das Alte Testament (18th ed.; vols. 1-; rev. R. Meyer et al.; Berlin: Springer, 1987-), 2:488. Cazelles's argument that the term הוקע means dismemberment builds on several shaky planks ("David's Monarchy," 168-69; see further n. 45 below). Polzin gives a more balanced discussion ("HWQYc," 231-33). Eliezer Ben Yehuda argues for two unrelated stems 'ק'יע, one meaning dislocation and the other hanging or crucifixion (A Complete Dictionary of Ancient and Modern Hebrew [in Hebrew; 17 vols.; repr. and compl., Tel Aviv: La'am Publishing House, 1948-1959], 4:2133, col. 2 n. 1). For

This article was published in JBL 122/1 (2003) 23-52, copyright $(\odot 2003$ by the Society of Biblical Literature. To purchase copies of this issue or to subscribe to JBL, please contact SBL Customer Service by phone at 877-725-3334 [toll-free in North America] or 802-864-6185, by fax at 802-864-7626, or visit the online SBL Store at www.sbl-site.org. 
either Michal (MT) or Merab (LXX). ${ }^{13}$ Honoring the covenant he had made with Jonathan (1 Sam 18:3-4; 20:8, 12-17, 23, 42), though, David spares Jonathan's son, Mephibosheth (see 2 Sam 9:1-13). The Gibeonites impale all seven descendants together. ${ }^{14}$ Rizpah protects the exposed bodies from birds

possibly relevant ancient Near Eastern iconography, see Samuel E. Loewenstamm, Encyclopedia Miqra'it, 2.798-800 (Hebrew).

${ }^{13}$ Scholars overwhelmingly prefer Merab because of the cumulative versional weight and since, according to the narrative, Michal did not bear any children (2 Sam 6:23) and Adriel was Merab's husband (1 Sam 18:19). For further arguments, see P. Kyle McCarter, Jr., II Samuel: A New Translation with Introduction, Notes, and Commentary (AB 9; Garden City, NY: Doubleday, 1984), 439. To Stoebe's challenge, "What reasonable motivation can be found for this slip of the pen?” (Das zweite Buch Samuelis, 454, v. 8 n. d), Walters already suggested a deliberate change meant to reassign Merab's inexplicable lack of maternal instinct to the already negative figure of Michal ("Childless Michal, Mother of Five," 291-94). For other attempts to uphold the MT, see J. J. Glück, "Merab or Michal," ZAW 77 (1965): 72-81; Zafrira Ben-Barak, "The Legal Background to the Restoration of Michal to David," in Studies in the Historical Books of the Old Testament (ed. J. A. Emerton; VTSup 30; Leiden: Brill, 1979), 15-29, at 27.

14 The LXX tradition, echoed in $y$. Sanh. 6.9, 23d, locates the site at Gibeon; the MT at Gibeat Saul. Driver reconstructs a series of corruptions leading to the MT, in which the original Hebrew text, בגבעון בהר הגול הגון בחיר ה' becomes, then is "understood in the sense of" MT

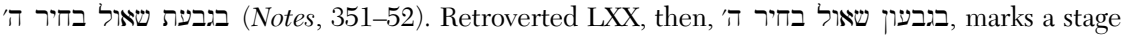
immediately prior to the MT. However, not one Greek version preserves a hint of this divine "mount," referring unanimously, rather, to YHWH's "chosen." It also seems odd that the impossible phrase גבעון שאול should ever have existed at all as a corrective stage in the development of the text. Driver's argument that somone understood Gibeon as Gibeat Saul lacks conviction as well. Finally, note the overloaded and overlapping modifiers in the original text Driver posits: והוקענום לה' בגבעון Anyway, nowhere does the Bible refer to a mountain other than Jerusalem's Temple Mount as "YHWH's mount" (except for Sinai in Num 10:33; on Gen 22:14, see Hermann Gunkel, Genesis [trans. M. E. Biddle; Macon, GA: Mercer University Press, 1997], 233-40, esp. 236, 237-38). Blenkinsopp suggests that the original text, close to the MT, read בגבעון אשר בחר ה', and a Deuteronomistic editor changed it to remove the conflict with the Jerusalem sanctuary chosen by YHwH in D ("Are There Traces," 211-12 n. 15). The reading, though, raises more literary, historical, and literary-historical questions than the text-critical ones it answers.

To work through this knotty passage, one perhaps should begin with the surprising phrase . Amיר הi. Apparently late, as basic concordance work reveals, the phrase most probably represents a sympathetic gloss on "Saul" (which now reads either as the narrator's lament, or as the Gibeonites' expression of outrage and poetic justice: YHWH's own elect has violated YHWH's vow and therefore deserves impalement to and before YHWH). This leaves the original text containing either Gibeon or Gibeat Saul. Given that "Saul" appears uniformly alongside both readings, Gibeon as well as Gibeat, it seems reasonable to infer that Gibeat represents the original text, as in the MT, and furthermore that the gloss בחיר הגentered the text before Gibeat became Gibeon. In this case, either the copyist penning the LXX Vorlage slipped, writing Gibeon for Gibeat, perhaps because the story concerns the Gibeonites (so Mr. Michael Segal), or else it may manifest discomfort with the idea of impaling Saul's children at Saul's own hill. For additional, subtle literary and historical arguments for preferring MT Gibeat Saul as the site of the temple mentioned in the story, see Menahem Haran, Temples and Temple Service: An Inquiry into Biblical Cult Phenomena and the Historical Setting of the Priestly School (2d ed.; repr., Winona Lake, IN: Eisenbrauns, 1995), 35-36 and nn. $42-43$.

This article was published in JBL 122/1 (2003) 23-52, copyright @ 2003 by the Society of Biblical Literature. To purchase copies of this issue or to subscribe to JBL, please contact SBL Customer Service by phone at 877-725-3334 [toll-free in North America] or 802-864-6185, by fax at 802-864-7626, or visit the online SBL Store at www.sbl-site.org. 
and beasts for an extended period of time, ${ }^{15}$ from the beginning of the harvest season until a downpour signals the end of her vigil, probably at the end of the entire harvest season. ${ }^{16}$ Hearing of this exemplary devotion and apparently moved to sympathetic response, David retrieves the bones of Saul and Jonathan from Jabesh-gilead, where they have lain since the heroes of Jabeshgilead recovered them from the Philistines in Beth-shan (1 Sam 31:8-13; 2 Sam $2: 4-7 ; 1$ Chr 10:6-12), and reinters them in the family plot in Benjamin:

He brought up the bones of Saul and the bones of his son Jonathan from there. They gathered the bones of those impaled. They buried the bones of Saul and his son Jonathan in Zela, in the territory of Benjamin, in the tomb of his father Kish. (2 Sam 21:13-14a $)$

The thread at this point begins to show loose ends. In between David's return with the bones of Saul and Jonathan (vv. 12-13a) and his burial of those bones (v. 14aa), the text points out that the bones of the sons impaled by the Gibeonites were collected (v. 13b), yet it does not determine what happened to

${ }^{15}$ Perhaps some midrashic relationship exists between the names Rizpah and Aiah, on one hand, and Rizpah's action of pitching her tent on the rock to keep the vultures at bay, on the other, since the name Rizpah could refer to a stone, as in 1 Kgs 19:6; Isa 6:6; Ezek 40:17, 18; 42:3; Esth 1:6; 2 Chr 7:3 (so already Moshe Garsiel, Biblical Names: A Literary Study of Midrashic Derivations and Puns [Ramat Gan: Bar Ilan University Press, 1991], 51), and the name Aiah could mean hawk or falcon. On the meanings of the names, see Martin Noth, Die israelitischen Personennamen im Rahmen der gemeinsemitischen Namengebung (Stuttgart: Kohlhammer, 1928; repr., Hildesheim/New York: Georg Olms, 1980), 230, 232; Ran Zadok, The Pre-Hellenistic Israelite Anthroponymy and Prosopography (Leuven: Peeters, 1988), 91, 92 n. 35.

${ }^{16}$ Regarding the phrase used for the season in which the sons die, Sebastian P. Brock reconstructs an original text בימי זיו תחילת קציר שערים (in the days of Ziv, the beginning of the barley harvest"), perhaps hinted at by LXX Luc ("An Unrecognized Occurrence of the Month Name Ziw (2 Sam. XXI 9),"VT 23 [1973]: 100-103). McCarter further emends MT v. 9bß to בימי הקציר הראשון (II Samuel, 439). However, tracing the devolution of the fine Hebrew Vorlage behind LXX Luc into the corrupted reading of the MT would require an implausible number of steps or an inordinate amount of speculation. Rather, the MT may contain a doublet caused by the insertion of a marginal gloss, now v. 9b $\gamma$, meant to delimit the general language of v. $9 \mathrm{~b} \beta$ (see already Stoebe, Das zweite Buch Samuelis, 455, v. 9 n. d, and the predecessors noted there), and the Hebrew Vorlage behind LXX Luc looks like a subsequent attempt to simplify the text (but note the elegant form of the whole now, concentric and rhyming). Although at first glance $y$. Qid 4.1, 65c seems to support this view: והמה הומתו בימי קציר בראשונים כתיי קציר שעורים, parallel texts in y. Sanh. 6.9, 23d and

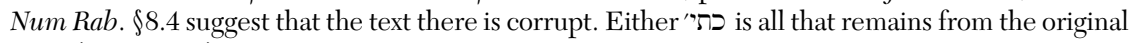
text, בתחילת כתי' תחילת (compare the style of the qere-kethib comment in y. Sanh. 6.9, 23d regarding שבעים and emend there to as in y. Qid.4.1,65c), or else it derives from what simply read

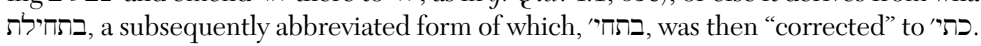

Regarding when the vigil ended, rabbinic tradition unanimously holds that the rains fell at the end of the summer (e.g., Mishnat Rabbi Eliezer [ed. H. Enelow; New York: Bloch, 1933], 166, lines 12-14; Midr. Sam. $\$ 28.6$ cites two different specific dates). Moderns, however, debate the point; Fokkelman's arguments support the rabbinic view (Throne and City, 287-88).

This article was published in JBL 122/1 (2003) 23-52, copyright $(\odot 2003$ by the Society of Biblical Literature. To purchase copies of this issue or to subscribe to JBL, please contact SBL Customer Service by phone at 877-725-3334 [toll-free in North America] or 802-864-6185, by fax at 802-864-7626, or visit the online SBL Store at www.sbl-site.org. 
them: Were they, for instance, buried or perhaps burned (compare 1 Sam 31:12-13)? The list of buried parties in v. 14 implies that if the sons did receive burial, they did not make it into the family plot in Benjamin, which raises several questions, such as, Why not? Furthermore, the subject switches suddenly from singular to plural: David returns the bones of Saul and Jonathan (vv. 12-13a), while "they" gather the bones of the sons impaled by the Gibeonites

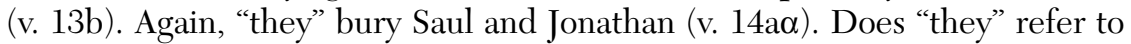
the same group of people in both cases, although "they" engage in two activities the text leaves unrelated? Finally, to whom does the next statement, "they did whatever the king commanded" (v. 14aß), refer-the group of people who collected the bones, the group who buried Saul and Jonathan (if it is a different one), or yet a third group?17 The emphasis in such a statement seems out of place in this story, which from the beginning depicts David as the one fulfilling demands, not issuing commands. ${ }^{18}$

Translations, ancient and modern alike, have attempted to circumvent these problems through several means. After the phrase "and [LXX: the bones]

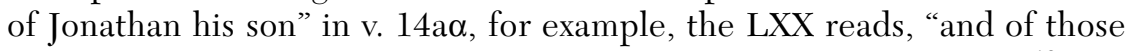

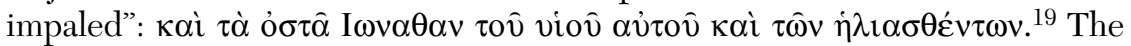
plus, though, creates new problems. First of all, it makes the predicate awkward, since the singular pronoun "his" follows two antecedents, "those impaled" as well as "Saul": "They buried the bones of Saul . . . and of those impaled . . . in the tomb of his father Kish." 20 It is clear what the verse must mean, but had the plus subordinated "those impaled" to "Saul" merely by



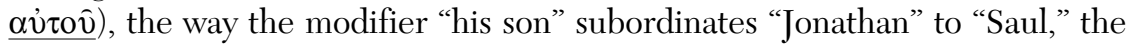
verse would have read better: "They buried the bones of Saul and ... of his impaled sons ... in the tomb of his father Kish." ${ }^{21}$ Second, rather than repeat

${ }^{17}$ Contrast the clarity in 2 Sam 4:12.

${ }^{18}$ The rabbis recognized that the statement does not refer back to the removal and burial of those impaled, vv. 13b-14aa; they therefore invented a different command given by David (Num. Rab. $\$ 8.4$ [end] and Pirqe R. El., ch. 17). See further n. 31 below.

${ }^{19}$ Alan E. Brooke and Norman McLean, The Old Testament in Greek, Volume 2, The Later Historical Books, Part 1, I and II Samuel (Cambridge: Cambridge University Press, 1927).

${ }^{20}$ Peter R. Ackroyd alludes to this problem (The Second Book of Samuel [CBC; Cambridge: Cambridge University Press, 1977], 199-200). Fokkelman comments elegantly on the MT: "After long wanderings Saul finally lies between 'his father' and 'his son' who are both so designated in relation to the first king" (Throne and City, 289).

${ }^{21}$ Tantalizingly, LXX B reads $\tau \hat{\omega} v \dot{\eta} \lambda \iota \alpha \sigma \theta \dot{\varepsilon} v \tau \omega v \underline{\tau \hat{\omega} v}$, as if about to introduce a modifier, but then skips abruptly to the location of the burial, $\dot{\varepsilon} v \gamma \hat{n}$ Bevı $\alpha \mu \varepsilon \iota v$ ("in the land of Benjamin"). The

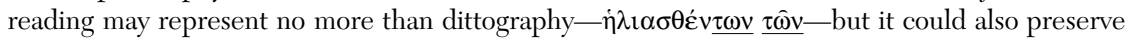
the remains of an attempt to improve the verse with an addition such as $\tau \hat{\omega} v$ vi $\hat{\omega} v$ av̉ $\tau o \hat{v}$ ("his sons"); interestingly enough, BHS (ad loc.) signals a lacuna after the second $\tau \hat{\omega} v$ rather than dittography.

This article was published in JBL 122/1 (2003) 23-52, copyright @ 2003 by the Society of Biblical Literature. To purchase copies of this issue or to subscribe to JBL, please contact SBL Customer Service by phone at 877-725-3334 [toll-free in North America] or 802-864-6185, by fax at 802-864-7626, or visit the online SBL Store at www.sbl-site.org. 
the governing phrase "and the bones," which in the LXX appears with both Saul and Jonathan, the plus relies on the prior mention with Jonathan: "the bones of Saul and the bones of Jonathan his son and of those impaled." Better style, at least for a Hebrew Vorlage, would employ the governing "bones" with each of the three objects. ${ }^{22}$ From the text critic's standpoint, one must also explain plausibly how the plus dropped out of the MT, especially when one can readily appreciate why the LXX would have added it. No such explanation has been offered. ${ }^{23}$

Such literary and textual phenomena regularly signal secondary work focused on solving a particular crux. In this case, it appears that the LXX has attempted to smooth out rough spots in the text. ${ }^{24}$ The original Hebrew text probably read, "the bones of Saul and Jonathan his son." An early scribe added the contextual harmonization, "and of those impaled." Within the LXX, subsequent scribes variously preceded that interpolation and "of Jonathan" by the stylistically unifying element, "the bones." ${ }^{25}$

Other translations and commentators variously transform the plural subjects to the singular or take the plural as the indefinite subject and rephrase it in the passive: the bones were collected, Saul and Jonathan were buried, all was done in accordance with David's command. ${ }^{26}$ However, even if one overlooks the subjective, obfuscating, and perhaps incorrect nature of the renderings, still

${ }^{22}$ See GKC $\$ 128 \mathrm{a}$, and, with greater nuance, Paul Joüon, A Grammar of Biblical Hebrew (rev. T. Muraoka; SubBi 14/1-2; Rome: Pontificio Istituto Biblico, 1996), \$129b. The few LXX manuscripts that do have "and the bones" before "of those impaled" (M, N, and several cursives) probably attest to a later effort to unify the style in the verse.

${ }^{23}$ See McCarter, II Samuel, 440. One has to wonder whether the midrash that cites 2 Sam 21:14 as a proof text for the idea that the death of the righteous brings atonement has this plus in mind and refers not to Saul, who died long before this episode, but to the seven sons, whose death, capped by burial, brought atonement; see Tan. B. Aharei $\$ 10$; Pesiq. Rb. Kah. $\$ 26.11$ (end); Lev. Rab. $\$ 20.7$ (end).

${ }^{24}$ Contra Driver, Notes, 352. Note that Driver accepted the plus in the LXX, but did not follow the LXX in repeating "and the bones" before "of Jonathan his son," leading again to a less probable text.

${ }^{25}$ It seems likely that "the bones" entered v. 14a to precede "of Jonathan" prior to the addition of "of those impaled," under the influence of vv. 12-13. Those few LXX manuscripts also adding $\pi \alpha \dot{v} \tau \tau \omega v$ ("all") before $\tau \hat{\omega} v \dot{\eta} \lambda \iota \alpha \sigma \theta \varepsilon \dot{v} \tau \omega v$ ("of those impaled") seem to stress Rizpah’s success in protecting the corpses—not one bone was lost—and perhaps even laud her for guarding Michal's sons, too.

${ }^{26}$ On the indefinite subject in Biblical Hebrew, see GKC $\$ 144$ d-i; Chaim Rabin, "The Ancient Versions and the Indefinite Subject," Textus 2 (1962): 60-76; idem, The Meanings of the Grammatical Forms in the Language of the Bible and of Our Own Times (in Hebrew; Jerusalem: Akademon, 1971-72), 39-42; Joshua Blau, A Grammar of Biblical Hebrew (Wiesbaden: Harrassowitz, 1976), \$70.1; Bruce K. Waltke and M. O’Connor, An Introduction to Biblical Hebrew Syn$\operatorname{tax}$ (Winona Lake, IN: Eisenbrauns, 1990), \$4.4.2; Joüon-Muraoka, Grammar of Biblical Hebrew,

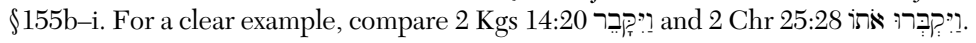

This article was published in JBL 122/1 (2003) 23-52, copyright $(\odot 2003$ by the Society of Biblical Literature. To purchase copies of this issue or to subscribe to JBL, please contact SBL Customer Service by phone at 877-725-3334 [toll-free in North America] or 802-864-6185, by fax at 802-864-7626, or visit the online SBL Store at www.sbl-site.org. 
none of the permutations put forward resolves all the issues. ${ }^{27}$ The very variety of solutions proposed, the lack of consensus, and the problems left unsolved argue for something other than a text-critical solution.

To offer an alternative, the various difficulties-narrative disjunctures and syntactical anomalies-may signal the mechanical, yet deliberate, even judicious, intertwining of two different stories. ${ }^{28}$ Note first that in vv. 13-14 the narrative thread has frayed and tangled. In terms of both the elliptical alternation in subject and the gaps and inconsistencies in narrative logic, the verbal clauses do not follow smoothly upon one another. However, when disentangled, they do link up into two continuous, logical narrative strands formulated consistently.

The first disjuncture, as noted, occurs between vv. 13a and b. Taking v. 13a, then, as the point of departure for disentangling the strands, it clearly follows v. 12 and picks up again in v. 14aa. All three segments deal with David's reburial of Saul and Jonathan. Moreover, when strung together, these clauses make up a continuous strand and a complete episode, however brief. True, the MT in v. 14a $\alpha$ has the plural verb "they buried," which would seem to sap the argument of its thrust, but LXX A and Luc preserve the singular here. ${ }^{29}$ Such a text attests a smooth, consistent narrative centered on a single active subject, David, and formulated to convey this focus grammatically. ${ }^{30}$

Setting this short narrative strand aside and recognizing that v. $14 \mathrm{~b}$ unquestionably concludes the story in vv. 1-11, the remaining clauses, formulated in the plural, include vv. $13 \mathrm{~b}$ and $14 \mathrm{a} \beta$. The clause in v. 13b, which mentions "those impaled," resumes the story in vv. 1-11 and anticipates its conclusion in v. 14b. Though not as transparently, v. 14a $\beta$ belongs with this text, too (see the following). 31

${ }^{27}$ Intimating vv. 12a $\alpha$ and 13a as something of a repetitive resumption, Budde simply excises almost all of v. 12 as a gloss, similarly removes v. 13b, and, like Smith (Books of Samuel, 377), proposes emending v. ויקברו ("they buried") to ויקברו ("he buried them") and taking the direct object marker $\mathrm{s}$ in the prepositional sense, "with": "and he buried them with the bones of Saul ..." (Die Bücher Samuel, 309). But, beyond the very fact of this rather casual wholesale revision, Budde cites no textual evidence and brings no other examples of mem-waw interchanges.

${ }^{28}$ For the poetics of the combined text, see, e.g., Fokkelman, Throne and City, 271-92; see also section $\mathrm{V}$ below.

${ }^{29}$ Given the revised nature of LXX A and Luc, the variant most likely reflects a genuine Hebrew Vorlage (see Emanuel Tov, The Text-Critical Use of the Septuagint in Biblical Research [rev. ed.; Jerusalem: Simor, 1997], 151-53). In addition, the complicated reading with the singular verb in LXX A and Luc (ויאספו ... ויקבר . . ויעשו), the homogeneity of the plural verbs in MT vv. 13-14 (ויאספו . . . ויקברו . . ו ויעשו) -whether produced deliberately or through scribal error-and the diversity among the versional emendations, together make it appropriate to apply here the principle of the primacy of difficult readings.

${ }^{30}$ Stoebe rightly affirms the emphasis on David as the actor (Das zweite Buch Samuelis, 455, v. 12 n. a).

${ }^{31}$ In this division, I have been anticipated by Ackroyd, in his comment on v. 13 (Second Book of Samuel, 199): "The removal of the bones of Saul and Jonathan is here amplified with a reference

This article was published in JBL 122/1 (2003) 23-52, copyright ( 2003 by the Society of Biblical Literature. To purchase copies of this issue or to subscribe to JBL, please contact SBL Customer Service by phone at 877-725-3334 [toll-free in North America] or 802-864-6185, by fax at 802-864-7626, or visit the online SBL Store at www.sbl-site.org. 
Fleshing out the narrative logic in this strand, the story tells how, with David's help, the Gibeonites avenged themselves against the house of Saul. The story begins with the famine (v. 1) and runs through the report reaching David of Rizpah's moving act of devotion (v. 11); it continues with the Gibeonites removing the bones of the impaled (v. 13b), perhaps because Rizpah effectively prevented their dispersal and so managed even to soften the Gibeonites' resolve for complete vengeance. ${ }^{32}$ The story then notes the Gibeonites' loyalty to David from then on in return for his cooperation (v. 14aß). ${ }^{33}$ Finally, it closes with God's complete propitiation (v. 14b). ${ }^{34}$

Precisely because the conflator did not harmonize the two sources by revising them to flow more smoothly, but simply spliced them together, the following eclectic translation can illustrate the division into two stories with roman and italic typefaces: ${ }^{35}$

to those of the seven men of verses $6-10$, but both the preceding verse and verse 14 strongly suggest that the original story here concerned only Saul and Jonathan, and that this act of piety by David ... has been subsequently combined with the other narrative." However, Ackroyd's tersely expressed insight has had no discernible impact on subsequent scholarship to date.

32 Ackroyd seems to identify v. 13b as a harmonizing addition (Second Book of Samuel, 199-200), but no substantive reason exists not to attribute it to this story, which, to the contrary, would suffer a gap without it. Ackroyd may have disliked the distance between the pronoun "they" in v. $13 \mathrm{~b}$ and its antecedent, "the Gibeonites," back in v. 9, with the Rizpah material intervening. However, Stoebe raised the likelihood that Rizpah's interlude itself is secondary (Das zweite Buch Samuelis, 460). In this scenario, Ackroyd could be correct, that the Gibeonite story originally had no burial whatsoever, but once the added Rizpah material made burial an issue, v. 13b followed with the Gibeonites collecting the remains Rizpah had protected. On the relationship between Rizpah's protective actions and the Gibeonites collecting the bones, see further $\mathrm{n}$. 45 below.

${ }^{33}$ In non-Priestly biblical style, a comment of the type in v. $14 \mathrm{a} \beta$ rarely covers actions already completed; rather, it follows commands given but not yet fulfilled. Sensitive to this usage, the midrash did not infer from the expression "whatever the king commanded" the obvious, namely, a command by David to remove the corpses; rather it felt compelled to postulate a command whose fulfillment the story does not relate (Num. Rab. $\$ 8.4$ [end] and Pirqe R. El., ch. 17).

${ }^{34}$ Comparing the Gibeonite episode to the census catastrophe in 2 Sam 24, Blenkinsopp takes the use of Elohim in 21:14b and YHWH in 24:25 in the otherwise identical phrase, "Elohim/YHWH yielded to the earth," as "suggesting comparison with $\mathrm{E}$ and J in the Pentateuch" (Gibeon and Israel, 114 n. 40). However, the entire theme of the land's punishment and entreaty has no place in the story of 2 Sam 24, in which YHWH punishes the people directly. Most likely, because of the parallels already existing between the two stories and to reinforce the palistrophe in chs. 21-24, the compiler of the appendix copied God's receptiveness to the land's entreaty from the Gibeonites' story and tacked it on at the end of the census story; note the presumably secondary linkage in 24:1. On originally similar stories progressively revised to resemble each other further, see Yair Zakovitch, "Assimilation in Biblical Narratives," in Empirical Models for Biblical Criticism, 175-96.

35 On the terms, "eclectic" and "diplomatic," see Emanuel Tov, Textual Criticism of the Hebrew Bible (Minneapolis: Fortress; Assen/Maastricht: Van Gorcum, 1992), 20. The translation is adapted mainly from Tanakh: The Holy Scriptures-The New JPS Translation According to the Traditional Hebrew Text (Philadelphia: Jewish Publication Society, 1985). For רפי כansom" in v. 3, see Jacob Milgrom, Leviticus 1-16: A New Translation with Introduction and Commentary (AB 3; New York: Doubleday, 1991), 1079-84 esp. 1082-83.

This article was published in JBL 122/1 (2003) 23-52, copyright $\odot 2003$ by the Society of Biblical Literature. To purchase copies of this issue or to subscribe to JBL, please contact SBL Customer Service by phone at 877-725-3334 [toll-free in North America] or 802-864-6185, by fax at 802-864-7626, or visit the online SBL Store at www.sbl-site.org. 
[1] There was a famine during the reign of David, year after year, for three years. David sought an audience with YHWH. YHWH said, "Because of Saul and the House of Bloodguilt" - because he put Gibeonites to death. ${ }^{[2]}$ The king summoned the Gibeonites and told them. Now the Gibeonites were not of Israelite stock, but a remnant of the Amorites, to whom the Israelites had given an oath, yet Saul had tried to wipe them out in his zeal for the people of Israel and Judah. ${ }^{[3]}$ David asked the Gibeonites, "What shall I do for you? What shall I ransom, so that you will bless YHWH's estate?" [4]The Gibeonites answered him, "We have no claim for silver or gold against Saul and his household, and we have no claim on the life of any other man in Israel." He responded, "Whatever you say I will do for you." " ${ }^{5]}$ So they said to the king, "The man who massacred us and who plotted to eliminate us, so that we should not survive anywhere in the territory of Israel, ${ }^{[6]}$ let seven men from among his issue be handed over to us, and we will impale them to YHWH in Gibeat Saul, the chosen of YHWH." The king replied, "I shall deliver (them)." ${ }^{[7]}$ But the king spared Mephibosheth son of Jonathan son of Saul, because of the oath of YHWH between them, between David and Jonathan son of Saul.

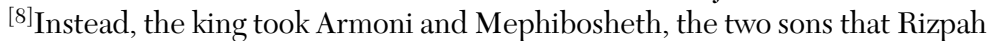
daughter of Aiah had borne to Saul, and the five sons that Merab daughter of Saul had borne to Adriel son of Barzillai the Meholathite, ${ }^{[9]}$ and he handed them over to the Gibeonites. They impaled them on the mountain before YHWH; all seven of them perished at the same time. They were put to death in the first days of the harvest, in the beginning of the barley harvest. ${ }^{[10]}$ Then Rizpah daughter of Aiah took some sackcloth and pitched it by a boulder (staying there) from the beginning of the harvest until rain from the sky fell on them (the corpses); she did not let the birds of the sky settle upon them by day or the wild beasts (approach) by night. ${ }^{[11]}$ David was told what Saul's concubine Rizpah daughter of Aiah had done. ${ }^{[12]}$ David went and took the bones of Saul and the bones of his son Jonathan from the citizens of Jabesh-gilead, who had made off with them from the public square of Beth-shan, where the Philistines had hung them up on the day the Philistines killed Saul at Gilboa. ${ }^{[13]}$ He brought up the bones of Saul and the bones of his son Jonathan from there. They gathered the bones of those impaled. ${ }^{[14]}$ He buried the bones of Saul and his son Jonathan in Zela, in the territory of Benjamin, in the tomb of his father Kish. And they did whatever the king commanded. After that, God yielded to the earth.

Once the linguistic, text-critical, and narrative data have prepared the basis for separating the two stories, additional aspects differentiating them further begin to take shape. When viewed on their own terms, apart from the rest of the narrative in the book of Samuel, the two stories identified develop alter-

This article was published in JBL 122/1 (2003) 23-52, copyright $(2003$ by the Society of Biblical Literature. To purchase copies of this issue or to subscribe to JBL, please contact SBL Customer Service by phone at 877-725-3334 [toll-free in North America] or 802-864-6185, by fax at 802-864-7626, or visit the online SBL Store at www.sbl-site.org. 
nate themes and take differing, even opposing positions on a variety of issues, from their respective portrayals of David, especially in his relation to Saul and his descendants, to their respective concern for the proper burial of Israelites.

In the story that takes up the majority of the pericope, an episode ushered in by a protracted famine lasting three years, David must send seven of Saul's progeny to their death for the good of the country. In Josh 9:3-27, YHWH stands behind the oath given to the Gibeonites, implying that he will demand retribution from the one who violates it. Saul, the text here explains, laid claim to that dubious distinction. ${ }^{36}$ Unless David as king takes upon himself the responsibility to pay up, YHWH will continue to make all Israel suffer. Whatever sympathy the depiction of Rizpah may elicit and however much the author may have attempted to qualify through it Saul's violation of the oath to the Gibeonites, the fact of this story remains that Saul bears the blame for the famine and, tragically, for its grisly resolution. ${ }^{37}$ David, on the other hand, keeps his vow to Jonathan and spares Mephibosheth. Ultimately, then, the story pits Saul against David on the issue of vows. Saul violates them, bringing death to his family; David upholds them, saving Saul's family. ${ }^{38}$

\footnotetext{
${ }^{36}$ Scholars, traditional and modern alike, have variously sought to identify the massacre. Candidates include the Nob episode in 1 Sam 22:9-19 (e.g., Hans W. Hertzberg, I \& II Samuel: A Commentary [OTL; Philadelphia: Westminster, 1964], 382; see already in particular Mishnat R. El., 165, lines 9-13, but also b. Yeb. 78b; b. B. Qam. 119a: Lev. Rab. \$22.3; Num. Rab. \$\$5.3; 8.4) and the cryptic remark in 2 Sam 4:2-3 (e.g., Moses H. Segal, "Studies in the Books of Samuel: Part II," JQR n.s. 8 [1917]: 98-99). Blenkinsopp contends that Saul made Gibeon his capital, which move may have eventually ended in the kind of falling out described in the case of Abimelech and Shechem in Judg 9 ("Did Saul Make Gibeon His Capital," 1-7, esp. 7). G. Henton Davies suggests an attempt by Saul to recover the lost ark ("Ark of the Covenant," IDB 1:222-26, at 224). See the review by McCarter, who himself feels that the massacre or campaign referred to belonged to a text no longer extant (II Samuel, 441; so already Wellhausen, Die Composition des Hexateuch, 260). In light of the general portrait of David in the book of Samuel as not responsible for the decimation of Saul and his house, and following those scholars who infer an attempt to hide David's true guilt (see n. 56, below), Meir Malul suggests that Saul never attacked the Gibeonites; rather, the story trumps up a pretext for David to do away with an entire group of Saul's descendants ("Was David Involved in the Death of Saul on the Gilboa Mountain?" RB 103 [1996]: 517-45, at 523 n. 25).

${ }^{37}$ The very aside clarifying Saul's guilt in v. 2 already softens the indictment by attributing his acts to "his zeal for the people of Israel and Judah" (see Rashi, ad loc.; Stoebe, Das zweite Buch Samuelis, 457). Compare Num 25:10-13, but note the contrast! Phinehas merits for himself and his descendants an eternal covenant of peace and a permanent place inside YHWH's abode, whereas Saul's children and grandchildren must die violently, and that—on the mountain "before YHWH," namely, either at the entrance to or across from his sacred precinct. Moshe Weinfeld raises the possibility that the story of the ruse by which the Gibeonites extracted an oath from the Israelites in Josh 9 meant to justify or at least mitigate Saul's actions (The Promise of the Land: The Inheritance of the Land of Canaan by the Israelites [Berkeley: University of California Press, 1993], 142).

${ }^{38}$ Emphasized already to a certain degree, although elaborated in a somewhat different direction, by Fokkelman (Throne and City, 281-82); see further in his comments for additional ways in which this story sets up a stark contrast between Saul and David (ibid., 277). Weinfeld links
} 
The second story, in which David returns the bones of Saul and Jonathan to the land of Benjamin, draws an entirely different kind of picture. ${ }^{39}$ It does not set David up against Saul. To the contrary, it continues the theme of David's respect, even love, for Saul and Jonathan, bringing it to a climax in what biblical narrative considers an ultimate act of loyalty, proper care for the dead. ${ }^{40}$ The text highlights this personal element by referring to David exclusively by his proper name, never once by the title "the king." This personal view of David contrasts with the story of the Gibeonites, which makes deliberate and effective use of David's official title, since David acts in his capacity as the person responsible for the nation as a whole and for the previous regime—namely, Saul-in particular.

Indeed, the story of the famine takes it for granted that the responsibility for the nation's well-being has already devolved upon David's shoulders, for which reason it falls to him to deal with the Gibeonites, fulfill their demands, and bring blessing to Israel. This story confirms David's position as king through the implied recognition of YHWH, who vouchsafes David the soughtafter oracle, and through the legitimate power it attributes to David to send seven of Saul's house to their deaths.

The brief report about David's care for Saul's and Jonathan's bones works with an alternate set of assumptions and approaches. It depicts David still in the throes of his attempt to establish his credentials as king. ${ }^{41}$ Presenting himself as the caretaker of the previous king's remains, namely, as the designated heir, as the king's "son," would have clear implications. ${ }^{42}$ This brief story, then, does not take as its starting point an implicit recognition of David's kingship and

the contrast between Saul, on one hand, and David and Solomon, on the other, in their treatment of the Gibeonites to a more thoroughgoing shift in overall policy regarding the ban on all Canaanite inhabitants ("Zion and Jerusalem," 79-81). Before him, Cazelles already emphasized David's general program of broadening his polity to include non-Israelite sectors and even of finding ways to incorporate their religious practices ("David's Monarchy and the Gibeonite Claim," 170-74). Gösta W. Ahlström goes so far as to claim that the ark David transferred to Jerusalem he brought from the Gibeonite cult ("The Travels of the Ark: A Religio-Political Composition," JNES 43 [1984]: 141-49, esp. 146 n. 22, 149; see already Blenkinsopp, "Did Saul Make Gibeon His Capital," 7).

${ }^{39}$ Fokkelman, an avowedly synchronic reader, calls it "a drastic change in the theme of the piece" (Throne and City, 272).

${ }^{40}$ For example, Gen 47:29-31; 2 Sam 2:5-6. The first story does also portray Rizpah's concern for the dead, but this element does not constitute the climax of that story or its main theme. If anything, it dramatizes David's predicament, pitting his sympathy for Rizpah's gruesome plight against the Gibeonites' rights to complete propitiation, which normally would conclude with the abuse and dispersion of the corpses through the hand of nature. David compromises, allowing both the Gibeonites to impale the sons and Rizpah to protect the bodies. See further n. 45 below.

${ }^{41}$ In historiographical terms, the two stories belong to two different periods in David's life. See further below, at the end of section III and in section IV.

${ }^{42}$ For David as Saul's son, see Tomoo Ishida, The Royal Dynasties in Ancient Israel: A Study on the Formation and Development of Royal-Dynastic Ideology (Berlin: de Gruyter, 1977), 71-80.

This article was published in JBL 122/1 (2003) 23-52, copyright @ 2003 by the Society of Biblical Literature. To purchase copies of this issue or to subscribe to JBL, please contact SBL Customer Service by phone at 877-725-3334 [toll-free in North America] or 802-864-6185, by fax at 802-864-7626, or visit the online SBL Store at www.sbl-site.org. 
further affirm it by illustrating the legitimate freedoms he may take with the previous royal family; rather, it centers on the role of David, still the aspiring heir to Saul, in bringing the odyssey of Saul's and Jonathan's remains to its proper and fitting conclusion. ${ }^{43}$

Both the story of Gibeonite vengeance and that of David's reinterment of Saul and Jonathan move toward the dressing of some open wound to bring rapprochement and closure, but the different narrative elements marshaled to effect this healing process do so in widely divergent ways. David, for instance, acts in a diametrically opposed manner from one story to the next. In the Gibeonite story, he gathers Saul's living remains in order to hand them over to an aggrieved group. In the reburial episode, he gathers Saul's and Jonathan's bodily remains and brings them home, completing their phased transfer from enemy hands to the Benjaminite hearth.

Relatedly, the stories differ in terms of the injured parties and the meaning behind the method of propitiation. In the Gibeonite pericope, Saul's violation of the vow in hunting down the Gibeonites creates two victims or plaintiffs, the Gibeonites, obviously, but YHWH as well, whose name and reputation Saul has willy-nilly put to the test. The impalement of the sons, then, which lasts for months, does more than exact judicial vengeance for the Gibeonites through vicarious talionic punishment. ${ }^{44}$ The setting of the famine, the divine oracle, David's use of the term כפר, the Gibeonites' power to bring blessing to "YHWH's estate," the ritual impalement of Saul's sons "before YHWH" (see 2 Sam 20:8; 1 Kgs 3:14-15), their nonburial, and the emphasis on YHwH's propitiation at the story's end, particularly the term ויעתר-all combine to affirm that impaling the sons amounts to a sacrificial offering to YHWH. ${ }^{45}$ So, indeed,

\footnotetext{
${ }^{43}$ Transferring the bones of a group's hero to the group's city constitutes one of the characteristic themes in Greek and Israelite "foundation" stories; see Weinfeld, Promise of the Land, 15, 34. Compare especially the case of Joseph's bones in Gen 50:25; Exod 13:19; and Josh 24:32.

${ }^{44}$ Contra Alexander F. Kirkpatrick (The Books of Samuel [CBC; Cambridge: Cambridge University Press, 1930], 414) and Raymond Westbrook (Studies in Biblical and Cuneiform Law [CahRB; Paris: Gabalda, 1988], 47-55, esp. 51 n. 54). In Num 25:4 a strictly judicial sense is equally insufficient; see further Arnold B. Ehrlich, Scripture According to Its Plain Meaning (in Hebrew; 3 vols.; Berlin: M. Poppelauer, 1899-1901; repr., New York: Ktav, 1969), 1:294; and Haran, "Impaling," 256-58, 264-65, 274. For straight bloodshed causing famine-but no vicarious impalement-see: in prose narrative, Gen 4:1-12; in poetry, 2 Sam 1:21; in prophecy, Ezek 22:1-24; in law, Num 35:31-34; extrabiblically, Aqhat 2 iv 16-3 i 46 (Ugaritic Narrative Poetry [trans. Mark S. Smith et al.; WAW 9; ed. S. B. Parker; Atlanta: Scholars Press, 1997], 165-69).

${ }^{45}$ For the sacral side of famine brought on by bloodguilt, see Alexander (Roifer) Rofé, "The Breaking of the Heifer's Neck" (in Hebrew), Tarbiz 31 (1962-63): 119-43, esp. 135-36; Moshe Weinfeld, "Inheritance of the Land—Privilege versus Obligation: The Concept of the 'Promise of the Land' in the Sources of the First and Second Temple Periods" (in Hebrew), Zion 49 (1984): 115-37, esp. 120-22. For the underlying concept as extended in Priestly thought to exile caused by sexual crimes, see Baruch J. Schwartz, The Holiness Legislation: Studies in the Priestly Code (in
} 
say the Gibeonites themselves: "we shall impale them to YHwh" (v. 6).46

The brief account of David's reburial of the remains of Saul and Jonathan, on the other hand, does not identify any plaintiffs. Neither God nor anyone else makes the demand to retrieve the royal bones; David is the sole actor. The story also establishes no crisis impelling David to act and, correspondingly, does not

Hebrew; Jerusalem: Magnes, 1999), 222-37, esp. 223-24, 232-37. On the root כפית, see Cazelles, "David's Monarchy," 167. On the history of the expression 'נחלת ה, see Samuel E. Loewenstamm, "Nah ${ }^{\mathrm{a}}$ lat YHWH," in Studies in Bible (ed. S. Japhet; ScrHier 31; Jerusalem: Magnes, 1986), 155-92; reprinted in Samuel E. Loewenstamm, From Babylon to Canaan: Studies in the Bible and its Oriental Background (Jerusalem: Magnes, 1992), 322-60. With regard to impalement, the only other instance in the Bible, Num 25:1-2, 3b-4, where the cause is not murder, similarly serves to propitiate YHWH through the death of Israel's leaders; see already Polzin, "HWQYc," 228-31; Poulssen, "Hour with Rispah," 188-89; and Blenkinsopp, "Are There Traces," 218 n. 43, who compares, among other parallels between Shechem and Gibeon, the ritual impalement of Saul's descendants and the seemingly ritual slaughter of Jerubaal's sons on one rock (Judg 9:5). On the root עת:ר, see Driver, Notes, 353, anticipated in the Zohar to Gen 25:21. On the vicarious punishment in the story as deriving from the sacral affront the majesty of God, see Moshe Greenberg, "Some Postulates of Biblical Criminal Law," in Studies in the Bible and Jewish Thought (Philadelphia/Jerusalem: Jewish Publication Society, 1995), 25-41, esp. 34-37 (originally published in Yehezkel Kaufmann Jubilee Volume [ed. Menahem Haran; Jerusalem: Magnes; 1960], 5-28). His analysis implies that the affront to God creates a pollution that infects the entire family. On the cultic significance of nonburial, see recently Stoebe, Das zweite Buch Samuelis, 455, v. 10 n. f.

${ }^{46}$ Many scholars have sought to recontextualize the impalement and perhaps dismemberment of Saul's progeny by reconstructing, on the basis of the Ugaritic Baal Cycle (CTA 6 II-III), a rite meant to facilitate rain and the growing of crops; they extended this interpretation to cover Rizpah's actions and so to uncover greater significance, either cultic or political or both, beneath the human pathos that both the impalement and Rizpah's act of devotion illustrate and evoke (Cazelles, "David's Monarchy," 167-70; Kapelrud, "King and Fertility," 41-50; Poulssen, "Hour with Rispah," 198-99; Frolov and Orel, "Rizpah on the Rock," 149-50). However, (1) ritual interpretations of the Baal Cycle, marred by critical faults (see The Ugaritic Baal Cycle, Volume 1 [ed. Mark S. Smith; VTSup 55; Leiden: Brill, 1994], 60-75), lay a weak foundation; (2) Rizpah's actions seem to derive midrashically from her name (see n. 15 above); (3) in Num 25:1-2, 3b-4, YHwH himself demands propitiatory impalement; and (4) ancient Near Eastern parallels preclude altogether the need to speculate about a supposed "Canaanite" fertility rite performed by the Gibeonites: impalement often served to punish treaty violation and often concluded with the birds and beasts preventing the proper burial of the violators' corpses (Polzin, "HWQYc," $228 \mathrm{n}$. 7; see further Jeffrey H. Tigay, Deuteronomy [JPS Torah Commentary; Philadelphia/Jerusalem: Jewish Publication Society, 1996], 198 and 382-83 nn. 59-62). On this basis, unaffected by McCarter's generic distinction between first-person prayer and third-person narrative "apology" (II Samuel, 445-46) and without undue speculation, one may safely say at most that by staving off the normal conclusion to the punishment for treaty-oath violation, Rizpah in effect mounts a tacit, de facto challenge to the proceedings, but not that she consciously intends to make a public political statement rejecting the legitimacy of David's pact with the Gibeonites (contra Cazelles). For this reason, the downpour does not signal YHWH's denunciation of David (contra Frolov and Orel). Indeed, the story's first speech has YHWH himself declare Saul's guilt, setting the grounds for all subsequent action. Most likely, the downpour indicates that the bodies had decomposed so thoroughly as no longer to draw the birds and beasts to carry them off, so the Gibeonites may as well come bury them. If the downpour signals something more than this defaulted end to the expiation process, it may highlight YHWH's own humanity. Rather than begrudge Rizpah the last respects she would pay her children, YHWH

This article was published in JBL 122/1 (2003) 23-52, copyright $(2003$ by the Society of Biblical Literature. To purchase copies of this issue or to subscribe to JBL, please contact SBL Customer Service by phone at 877-725-3334 [toll-free in North America] or 802-864-6185, by fax at 802-864-7626, or visit the online SBL Store at www.sbl-site.org. 
signal a moment of reconciliation. The final due David gives to Saul and Jonathan speaks entirely for itself as a purely human gesture; whatever ritual dimension may exist never penetrates the surface of the text.

Put in terms of legal assumptions, the two stories differ with regard to the prohibition found in Deut 21:22-23 against hanging the bodies of executed criminals overnight:

If a man is guilty of a capital offense and you impale him on a stake, do not let his corpse remain on the stake overnight; rather you shall bury him that very day, because an impaled body is an affront to God, and you shall not defile the land that YHWH your God is giving you as a possession. ${ }^{47}$

The story of the atonement for Saul's violation of the oath given to the Gibeonites directs criticism neither at the Gibeonite heirs, who probably expected or even desired that the wild animals would prey upon the corpses, nor at Rizpah, whose protection of the corpses kept them unburied for the duration of an entire agricultural season. ${ }^{48}$ Nowhere does the story so much as hint at a legal requirement to bury the impaled sons before nightfall. ${ }^{49}$ To the contrary, illustrating the care Rizpah gave evokes great sympathy for her. ${ }^{50}$ Moreover, God's complete propitiation depends on the Gibeonites' satisfaction, which they signal when they themselves collect the bones of the sons. Indeed, the text does not even bother to specify explicitly that the Gibeonites actually buried the bones. ${ }^{51}$ Put more succinctly, in the story, the display of the

allowed Rizpah her moment even though it forestalled the normal, proper conclusion for treaty violation and now the sons would receive their final rites.

${ }^{47}$ Moshe Weinfeld holds that the law means to reject the practice of propitiating God for treaty violation by publicly exposing the violators' corpses (Deuteronomy and the Deuteronomic School [Oxford: Oxford University Press, 1972; repr., Winona Lake. IN: Eisenbrauns, 1992], 51 n. 4). R. Meir Simha Hakohen of Dvinsk (1843-1925) explains the complicated syntax by the compositional principle that arranges two related statements in alternating clauses, as initial clause a + initial clause $\mathrm{b}+$ modifier $\mathrm{a}+$ modifier $\mathrm{b}$, or $\mathrm{a}_{1} \mathrm{~b}_{1} \mathrm{a}^{2} \mathrm{~b}^{2}$ : [a] "Do not let his corpse remain . . . because an impaled body is an affront to God" (overnight [v. 23a $\alpha+b \alpha]$ and [b] "rather, you shall bury him that very day ... so that you not defile the land that YHWH your God is giving you as a possession" [v. 23a $\beta+b \beta]$ ); see his commentary on the Pentateuch, Meshekh Hokhmah al Hatorah (ed. Y. Copperman; 2d ed.; 3 vols.; Jerusalem: Haskel, 1983), 3:152.

${ }^{48}$ Stoebe notes this contradiction (Das zweite Buch Samuelis, 455, v. 10 n. f).

${ }^{49}$ Recognized by Weisman, "Legal Aspects," 153. Ben-yashar rightly emphasizes Rizpah’s role in keeping the corpses unburied, but he overreaches when he argues that although the Gibeonites would have wanted the corpses buried Rizpah objected so that the blood would dry up first and not defile the land ("Study of the Pericope," 60 and n. 32). In biblical literature, legitimately spilled blood does not pollute the land; see Num 35:9-34. esp. vv. 33-34.

${ }^{50}$ Walters sees a further stab at the Saulide house: giving prominence to Rizpah ultimately highlights the absence of Merab/Michal at this tragic moment ("Childless Michal, Mother of Five," 293; see already Poulssen, "Hour with Rispah," 190 n. 1).

${ }^{51}$ Citing 2 Kgs 22:20, Kil argues that to be "collected" or "gathered" means burial (2 Samuel, 506). Even if he is correct, 2 Sam 21:13 does not emphasize the burial, only, in essence, the removal

This article was published in JBL 122/1 (2003) 23-52, copyright $@ 2003$ by the Society of Biblical Literature. To purchase copies of this issue or to subscribe to JBL, please contact SBL Customer Service by phone at 877-725-3334 [toll-free in North America] or 802-864-6185, by fax at 802-864-7626, or visit the online SBL Store at www.sbl-site.org. 
corpses, propitiating God, saves the land; in the law, such display, insulting God, pollutes it. ${ }^{52}$

By contrast, the story relating how David retrieved Saul's and Jonathan's remains to reinter them in Benjamin focuses at the very least on some aspect of proper burial. When seen in conjunction with David's emphatic praise of the people of Jabesh-gilead for burying Saul (2 Sam 2:5), again, it seems that the correct context for this story consists of improper, insufficient, or temporary treatment of the bones and a concern to rectify the situation. ${ }^{53}$

III

When viewed in light of the running narrative in the book of Samuel, the distinctions between the two separate stories in 2 Sam 21:1-14 come into sharper focus. Each one continues different themes and picks up separate threads found in the larger narrative complex.

The catalyst for the action in the Gibeonite story, Saul's analeptically recounted sacral violation with its consequences, continues an important theme found in the cycle of stories surrounding Saul prior to David's arrival. Saul's confused relationship with vows and following YHWH's word has continually undercut him as a leader and led to the downfall of his kingship (see 1 Sam $13-15 ; 28) .{ }^{54}$ Now it has secured his demise and that of his house permanently.

To take one example, Saul's violation of the vow to spare the Gibeonites links up with the Amalekite episode in 1 Sam 15 in several ways. If Saul disqualified himself as king by botching the divine command to annihilate the Amalekites, he seals the fate of his house by again transgressing a divinely sanctioned word, this one against assaulting the Gibeonites. Both stories, then, share in presenting Saul's downfall through the violation of YHWH's will regarding the treatment of specific nations in and around Canaan. Moreover, the two

of the bones; note the different verbal conjugations as well (qal here, nip`al there). Moreover, Kil seems to contradict himself when he says that v. 14 should have mentioned the bones of those impaled (ibid.).

${ }^{52}$ See already b. Yeb. 79a; y. Qid. 4.1, 65c; y. Sanh. 6.9, 23d; Num. Rab. \$8.4; Midr. Sam., ch. 28. The midrash further notes that the accountability of Saul's house for his own sins illustrates another concept to which Deuteronomy objects, in Deut 24:16 (b. Yeb. 79a; Num. Rab. \$8.4; Midr. Sam., ch. 28). See further n. 86 below. Similarly, the midrash discusses why the famine did not come in Saul's days (Gen. Rab. 25:3; 64:2; Ruth Rab. 1:4; Midr. Sam., ch. 28; Yal. Sh. 247:153).

${ }^{53}$ Picked up on by the rabbis in y. Qid. 4.1, 65c; y. Sanh. 6.9, 23d; Midr. Ps. on Ps 17; Midr. Sam., ch. 28; Pirqe R. El., ch. 17; see Rashi on vv. 1 and 14.

${ }^{54}$ See, e.g., the analyses in Peter D. Miscall, 1 Samuel: A Literary Reading (Bloomington: Indiana University Press, 1986), 81-114; and Robert Polzin, Samuel and the Deuteronomist: A Literary Study of the Deuteronomic History, Part 2, I Samuel (San Francisco: Harper \& Row, 1989), 126-51, long anticipated by $1 \mathrm{Chr} 10: 13-14 ; 13: 3$.

This article was published in JBL 122/1 (2003) 23-52, copyright @ 2003 by the Society of Biblical Literature. To purchase copies of this issue or to subscribe to JBL, please contact SBL Customer Service by phone at 877-725-3334 [toll-free in North America] or 802-864-6185, by fax at 802-864-7626, or visit the online SBL Store at www.sbl-site.org. 
episodes join the narrative complex in Josh 2-9 in suggesting an unremitting and perhaps ideological Benjaminite belligerence toward the Canaanites that characterizes roughly Saul's time. ${ }^{55}$

The Gibeonite episode brings Saul's failures in this regard to a head. Ironically, Saul attempted to destroy the Gibeonites on Israel's behalf; instead, he ended up bringing famine upon Israel on the Gibeonites' behalf. Moreover, the only way to right this upside-down situation of Gibeonite domination required first going deeper into it: in a mirror image of the ban, the Gibeonites get to destroy Saul's family directly in ritual execution. Only after this process plays itself out can nature return to its proper and prospering course.

The Gibeonite story adds a new dimension to the grounds for contrasting David's success with Saul's failure. David ensures the future of his kingdom not by punctiliously carrying out the terms of the ban but by applying an alternative policy altogether, one of sociopolitical and perhaps religious inclusion. Throughout the story, David accedes to the demands made by the Gibeonites; after the Gibeonites avenge the wrong done to them, they obey whatever commands David issues: "And they did whatever the king commanded" (v. 14aß). This symbiotic relationship, so different from Saul's antagonism, merits the divine seal of approval illustrated by the famine's end: "After that, God yielded ..." (v. 14b). ${ }^{56}$

The Gibeonite story adds an important link to the chain of chapters chronicling the demise of Saul's house. Furthermore, it develops the theme running through those chapters, of how David's hands stay clean in the midst of that demise, as other forces gather to promote his cause. Up to this point in the narrative, two stories and one brief but pregnant note focus in detail on removing Saulide heirs from contention for the throne: the assassinations of Abner (2 Sam 3) and Ishbosheth (ch. 4) and Michal's lack of children (6:23). Viewed from a political point of view, David's patronage of Mephibosheth (ch. 9) may

\footnotetext{
55 So Moshe Weinfeld, "The Ban on the Canaanites in the Biblical Codes and its Historical Development," in History and Traditions of Early Israel: Studies Presented to Eduard Nielsen (ed. A. Lemaire and B. Otzen; VTSup 50; Leiden: Brill, 1993), 142-60, esp. 155-58; compare the related argument in Liver, "Joshua 9," 243, and see already Hertzberg, I \& II Samuel, 131. Stanley Walters's view that the genealogies of $1 \mathrm{Chr}$ 8-9 make Saul a Gibeonite as part of the Chronicler's general policy of denying Saul credibility as Israel's first king (“Saul of Gibeon," JSOT 52 [1991]: 61-76) renders the entire Gibeonite story here nonsensical. More likely the Chronicler drew that genealogy from an earlier source, which at its inception intended either to legitimate Saul's claim to kingship at Gibeon or else to bolster Gibeonite status within Israel. For parallel comments on how David's Calebite genealogy in $1 \mathrm{Chr}$ 2:50-51 served his rule at Hebron—contrast 1 Chr 2:9-17 and Ruth 4:18-22—see Jon D. Levenson and Baruch Halpern, "The Political Import of David's Marriages," JBL 99 (1980): 507-18, at 508-11. On genealogies, see Robert Wilson, Genealogy and History in the Biblical World (New Haven/London: Yale University Press, 1977).

${ }^{56}$ On David shifting Saul's policy on the ban, see Weinfeld, "Zion and Jerusalem," 79-81.
}

This article was published in JBL 122/1 (2003) 23-52, copyright $(\odot 2003$ by the Society of Biblical Literature. To purchase copies of this issue or to subscribe to JBL, please contact SBL Customer Service by phone at 877-725-3334 [toll-free in North America] or 802-864-6185, by fax at 802-864-7626, or visit the online SBL Store at www.sbl-site.org. 
belong to this set of stories as well, since, whatever the genuine fidelity to Jonathan, Mephibosheth's perpetual board "at the king's table" effectively keeps him under David's watchful eye, much as David's request for Michal may intend to contain her as well as reinforce the continuity between him and Saul (3:14). Lame in both feet, Mephibosheth may not have posed the kind of threat that invited the measures David's supporters deemed appropriate for Abner and Ishbosheth. The story of Gibeonite vengeance against Saul's family brings closure to the trend-begun with the introductory remark that the house of Saul progressively diminishes, while the house of David increasingly develops (3:1) — with emphatic finality. Seven potential agitators meet their fate "in one fell swoop," as the text itself emphasizes (21:9). ${ }^{57}$ Here, not only does Saul's house diminish and as a result David's house strengthen, but David himself plays the part of the pivot. 58

\footnotetext{
${ }^{57}$ Note the similar emphasis in 1 Sam 31:6. The parallel text in 1 Chr 10:6 alters 1 Sam 31:6 by replacing "his people" with "his house," removing the temporal modifier "that day" and adding a second predicate. These changes result in a verse containing two independent clauses: "Saul died with his three sons, and his entire house fell together," with the new, second clause perhaps making oblique reference to the Gibeonite episode, which Chronicles otherwise passes over in silence. For alternative analyses, see Alexander Rofé, "The Battle of David and Goliath: Folklore, Theology, Eschatology," in Judaic Perspectives on Ancient Israel (ed. J. Neusner et al.; Philadelphia: Fortress, 1987), 117-51, esp. 145 n. 10, and Yaira Amit, "Three Variations on Saul's Death" (in Hebrew), Bet Mikra 30 (1985): 92-102, but contrast altogether Craig Y. S. Ho, "Conjectures and Refutations: Is 1 Samuel XXXI 1-13 Really the Source of 1 Chronicles X 1-12?" VT 45 (1995): 82-106 at 85-87 (and the literature surveyed there).

${ }^{58}$ Noted by Tomoo Ishida, History and Historical Writing in Ancient Israel: Studies in Biblical Historiography (Leiden: Brill, 1999), $158 \mathrm{n}$. 1. It is tempting to respond to this theme by paraphrasing the queen's remark to Hamlet (III.ii.230) - the author doth protest too much, methinks - and to follow those scholars who see in it an apology meant to deny David any role in the methodical elimination of Saul's house (Ehrlich, Scripture, 2:247; P. Kyle McCarter, Jr., "The Apology of David," JBL 99 [1980]: 489-504; James C. VanderKam, "Davidic Complicity in the Deaths of Abner and Eshbaal: A Historical and Redactional Study," JBL 99 [1980]: 521-39; Frederick H. Cryer, "David's Rise to Power and the Death of Abner," VT 35 [1983]: 385-94: Polzin, David and the Deuteronomist, 206-7; Malul, "Was David Involved in the Death of Saul on the Gilboa Mountain?"; see also Ishida, History and Historical Writing, 158-65). However, caution advises against singling out the definitive agenda in these stories with too much confidence. Without the control provided by additional texts, which could confirm several of the details in the stories or, better, offer a different slant on the same general events, it is difficult to separate fact from spin. In an alternative scenario, for instance, the narrative may be telescoping several distant, unrelated, and apolitical Saulide deaths into a brief period and attributing them to David's supporters in order to dramatize David's charm. The theme in this case, rather than countering David's notorious ruthlessness, serves to glorify his ascent by taking a mundane, drawn-out process and recasting it as an inspiring, action-packed account of the extreme devotion the hero aroused. Another reading, akin to but somewhat blacker than Jotham's parable (Judg 9:6-20) and worse than anything Samuel predicted (1 Sam 8:11-18; 12:13-15, 20-25), would infer the message that kingship substitutes one kind of instability for another, or, if one prefers the more optimistic spirit in Samson's riddle (Judg 14:14), that the blessing of kingship emerges through violence. Such protean multivalence renders
}

This article was published in JBL 122/1 (2003) 23-52, copyright $@ 2003$ by the Society of Biblical Literature. To purchase copies of this issue or to subscribe to JBL, please contact SBL Customer Service by phone at 877-725-3334 [toll-free in North America] or 802-864-6185, by fax at 802-864-7626, or visit the online SBL Store at www.sbl-site.org. 
Related to these same chapters through an additional element, the Gibeonites' story also picks up the thread pertaining to Rizpah, Saul's concubine. Twice this woman finds herself in the middle of David's efforts to forge new alliances at the expense of Saul and his house, alliances seemingly bound up with the ability to rule over a contiguous Israel.

The first time-so the narrator reveals analeptically and through the direct speech of the characters-Abner had slept with Rizpah, in a power play originally meant to crown his rise within the house of Saul and establish himself as Saul's successor. Ultimately, however, the move led to his defection to David's camp, for when Ishbosheth later recalls the seditious incident, Abner throws his lot in with David, probably in an effort to save his life (2 Sam 3:6-21) - fruitlessly, as it turns out (2 Sam 3:22-27). Structurally, Abner fills two parts in this, his final episode: the potential successor who meets an untimely death and the party joining David's ranks.

The second time Rizpah appears, Abner's dual role splits itself into two characters, or two groups of characters: Rizpah's sons, who suffer an early death because of their status as potential successors to Saul, and the Gibeonites, whose territory, according to those reading the story with an eye toward military and political geography, had cut Saul's kingdom in two, in a swath separating north from south. ${ }^{59}$

Abner had sworn to Ishbosheth that he would hand David the entire kingdom, "from Dan to Beer-sheba" (2 Sam 3:9-10); indeed, he strode the halls of Israelite power to campaign on David's behalf (vv. 17-19). Similarly, acceding to the Gibeonites' demands gains David their loyalty (21:14), which in effect gives him a territorially contiguous domain over which to establish and extend his rule.

Rizpah, in these two stories, serves as the linchpin joining the various parts that make up the plot's structure. In both, whoever has Rizpah, whether as wife/concubine or as mother, marks himself as an heir and potential rival to David, which amounts to slating himself for an early execution; and in both, the execution of those tracing their claims through Rizpah leads or should lead to a united territory for David to rule.

The structural alignments surrounding the figure of Rizpah do not merely repeat themselves in new but ultimately static terms. A change has occurred from one stage to the next. Abner did not fill two roles as an illustration of the

the relative transparency assumed in reconstructions of history from historiography rather opaque. See, too, Robert Alter, The David Story: A Translation with Commentary of 1 and 2 Samuel (New York/London: W. W. Norton, 1999), ix-xxiv; idem, The Art of Biblical Narrative (New York: Basic Books, 1981), 23-25; , and Stoebe's sharp criticism of the apologetic interpretation (Das zweite Buch Samuelis, 456, 459-60).

${ }^{59}$ Noted, e.g., by Blenkinsopp, "Did Saul Make Gibeon His Capital," 3.

This article was published in JBL 122/1 (2003) 23-52, copyright $@ 2003$ by the Society of Biblical Literature. To purchase copies of this issue or to subscribe to JBL, please contact SBL Customer Service by phone at 877-725-3334 [toll-free in North America] or 802-864-6185, by fax at 802-864-7626, or visit the online SBL Store at www.sbl-site.org. 
author's efficiency; rather he embodied the power still coursing through Saul's house. A claimant to the throne actually had sufficient stature within Israel to be able to promise its allegiance to his rival (2 Sam 2:8-9). By the time of the Gibeonite story, the limits of the kingdom depend not one whit on Saul's house, but rather on the people he meant to destroy; Saul's seven descendants die simply as a matter of political course. In addition to her role as structural linchpin, then, Rizpah also marks the slide of Saul's house. Underscoring this slide, David does not now take Rizpah for his wife, in the kind of politically advantageous move related in the case of Abigail. ${ }^{60}$

Finally, Gibeon itself does not make its first appearance in 2 Sam 21:1-14. Open hostilities between the houses of Saul and David first manifested themselves "by the pools of Gibeon" (2 Sam 2:12-3:1). Here, at Gibeon, David's ascent at the expense of Saulide and Benjaminite lives first begins, and here, at Gibeon, this process achieves closure: David sends a final batch of Saulides to their ritual deaths. ${ }^{61}$ Here, too, beginning and end show a dynamic movement, from a military struggle between ostensible equals to a situation in which Saul's descendants have no say in the matter of their deaths, from war to ritual execution.

To sum up, the story of Gibeonite vengeance draws on many of the thematic and structural elements of the stories in 2 Sam 2:12-6:23 and possibly also ch. 9. The common thread running through all these episodes is the essentially open contention between the Saulides and David, whether in military or less fatal, political manifestations. Moreover, in many respects, the Gibeonite story seals shut this chapter in David's rise, depicting his complete control over Saul's house. ${ }^{62}$

By contrast, the story of David's retrieval and reburial of the bones of Saul and Jonathan has no direct links to any of those episodes and themes. Rather, it seems related to a different theme, framed within a brief account, namely, how the heroes of Jabesh-gilead stole the bodies of Saul and his sons from the Philistines, facilitating their proper burial (1 Sam 31:8-13; 2 Sam 2:4b-7; 1 Chr 10:11-12). In this respect, David's reburial of the bones joins those accounts that feature a special relationship between Gilead, on one hand, and Saul and Benjamin, on the other (Judg 19-21, esp. 21:1-14; 1 Sam 11) ${ }^{63}$ In addition, the

${ }^{60}$ Note 2 Sam 12:7-8; see further Jon D. Levenson, "I Samuel 25 as Literature and History," CBQ 40 (1978): 11-28; Levenson and Halpern, "Political Import of David's Marriages"; also Matitiahu Tsevat, "Marriage and Monarchical Legitimacy in Ugarit and Israel," JSS 3 (1958): 23743, esp. 241-43.

${ }^{61}$ Noted in part by Polzin, David and the Deuteronomist, 213-14, but with different emphasis. For a further showdown by the pools of Gibeon (where, again, the royal side loses), see Jer 41:11-18.

${ }^{62}$ One can pursue this line of analysis between MT 2 Sam 21:8 "Michal” and 6:23 as well.

${ }^{63}$ For a succinct enumeration of points explaining the relationship between Saul and the

This article was published in JBL 122/1 (2003) 23-52, copyright $\odot 2003$ by the Society of Biblical Literature. To purchase copies of this issue or to subscribe to JBL, please contact SBL Customer Service by phone at 877-725-3334 [toll-free in North America] or 802-864-6185, by fax at 802-864-7626, or visit the online SBL Store at www.sbl-site.org. 
story also dovetails with David's attempts to win over Saul's tribesmen and allies in Benjamin and Jabesh-gilead, a campaign he began by slaying the Amalekite who boasted of dealing Saul his final blow (2 Sam 1:1-16) and continued by commending the citizens of Jabesh-gilead for rescuing the bodies of Saul and Jonathan from Philistine ignominy $(2: 4 \mathrm{~b}-7){ }^{64}$ These episodes belong to the period before the opening of direct military hostilities-before, in fact, Abner parades Ishbosheth throughout Israel, including Gilead, to make him king (2:8-9). At this stage, David still stands a chance of presenting himself as Saul's rightful heir. David's care for the remains of the royal family follows this policy.

This distinction in the historical period presumed by each of the two stories manifests itself in a phenomenon noted above. In the running text of the book of Samuel, the narrator does not actually begin openly to refer to David as "the king" until 2 Sam 3:24, after the pivotal character of Abner, who attempted to transfer the kingdom to David, has already done so, in 2 Sam 3:21. ${ }^{65}$ From then on, the alternation between title and personal name, and their order when standing in apposition ("King David" or "David the king"), often serve as signals of one sort or another for the discerning hermeneut. This alternation exists in the story of the Gibeonites. The brief report about David's reinterment of the remains of Saul and Jonathan, though, exclusively refers to David by his personal name, which suggests that the report belongs to the period prior to Abner's defection, or at least to the texts depicting that period.

IV

The contrast between the stories of Gibeonite vengeance and royal reinterment goes beyond the differences in theme, narrative stage, and background assumption. General scholarly opinion has it that the story of Gibeonite vengeance originally sat within the actual text containing its related narrative pieces. Most scholars (re)place the story immediately prior to David's search, in honor of Jonathan, for a surviving member of Saul's family (2 Sam 9:1-13),

Transjordanian region, see Blenkinsopp, "The Quest for the Historical Saul," in No Famine in the Land: Studies in Honor of John L. McKenzie (ed. J. W. Flanagan and A. Weisbrod Robinson; Missoula, MT: Scholars Press, 1975), 75-99, at 90-91. Among the prophets, Jeremiah, from Anathoth in Benjamin, draws on images of Gilead in several of his prophecies $(8: 22 ; 22: 6 ; 46: 11 ; 50: 19)$ and Obadiah envisions Benjamin retaking Gilead (19).

${ }^{64}$ Malul sees the Amalekite episode as part of the agenda to deny David's complicity in the destruction of Saul's house, in this case, in the murder of Saul himself; David kills the Amalekite to "tie up the loose end" ("Was David Involved," 531-36). James Ackerman adds that David's recurring concern with killing God's anointed could mean to establish a precedent so that his own methods do not come back to haunt him (oral communication).

${ }^{65} 2$ Samuel 2:11 is a proleptic summary comment with its own set of source-critical problems.

This article was published in JBL 122/1 (2003) 23-52, copyright ( $\odot 2003$ by the Society of Biblical Literature. To purchase copies of this issue or to subscribe to JBL, please contact SBL Customer Service by phone at 877-725-3334 [toll-free in North America] or 802-864-6185, by fax at 802-864-7626, or visit the online SBL Store at www.sbl-site.org. 
since David begins his search by voicing a presupposition to the effect that the majority of Saul's heirs are no longer alive:

Then David said, "Is there yet any other remnant of the House of Saul that I may treat him loyally for Jonathan's sake?” (v. 1)

In this case, David's sparing of Mephibosheth in 2 Sam 21:7 only makes sense as a subsequent harmonization necessitated by the inclusion of the text among the chapters appended to the book of Samuel. ${ }^{66}$ Others reject the hypothesis that the story originally preceded 2 Sam 9 and its corollary, that v. 7 constitutes an editorial harmonization. From the internal aspects of the story, no indications, literary or textual, warrant the excision of v. 7 from the original composition. Moreover, the narrative logic leading scholars to identify David's sparing of Mephibosheth in v. 7 as a secondary harmonization applies equally to the rest of the sons in v. 8: if David chose the sons given to the Gibeonites, how could he not have known of the existence and whereabouts of Mephibosheth and other sons? ${ }^{67}$ The entire Gibeonite story, then, with v. 7, originally followed David's patronage (or house arrest) of Mephibosheth in 2 Sam 9. According to this group of scholars, the Gibeonite episode provides the background of the assault by Shimei son of Gera on David (2 Sam 16:5-13), which similarly indicates that Saul's house met its demise and lays the charge at David's bloody hands:

Out! Out you unscrupulous murderer! YHWH has avenged all the bloodguilt

of Saul's house, in whose place you rule ... for you are a murderer! (vv. 7b-8)

And, they reason, within these two outer limits, 2 Sam 9 and 16, the break between chs. 9 and 10 provides the most appropriate location for the story. ${ }^{68}$

Although the analysis in sections II-III cannot provide the key to decide this debate, it may have repercussions for it. If the story of Gibeonite vengeance does imply that after the rapprochement with the Gibeonites

\footnotetext{
${ }^{66}$ So Budde, who adds that ויהי 21:14, originally preceded byally belongs to the following scene, beginning in 9:1 (Die Bücher Samuel, 244, 304-6, 309). See the convenient summary of arguments in VanderKam, "Davidic Complicity in the Deaths of Abner and Eshbaal," 537-39, and the fuller discussion with references in McCarter, II Samuel, 263-65.

${ }^{67}$ Moses H. Segal, The Books of Samuel (in Hebrew; Jerusalem: Kiryat-Sefer, 1957 [1976]) 366; see further Fokkelman, Throne and City, 283.

68 Moses H. Segal, "Studies in the Books of Samuel. IV and V," JQR n.s. 10 (1919-20): 421-44, esp. 439-44; Haran, "Impaling," 251, 274-75. Sensitive to what looks like a repetitive resumption ("son of Jonathan ... son of Jonathan") and the awkward style of v. 7b, Ehrlich takes an entirely different approach to v. 7. He suggests that David originally bypasses Mephibosheth because of the defect of lameness, which disqualifies him as a sacrifice. A later annotator, unaware of the sacrificial aspect of impalement, explained the move on the basis of 2 Sam 9:1. Ehrlich observes that David had also made a vow to Saul to spare his offspring (1 Sam 24:20-22): Why should he keep his vow to Jonathan, but betray the oath to Saul? (Scripture, 2:248).
}

This article was published in JBL 122/1 (2003) 23-52, copyright $(2003$ by the Society of Biblical Literature. To purchase copies of this issue or to subscribe to JBL, please contact SBL Customer Service by phone at 877-725-3334 [toll-free in North America] or 802-864-6185, by fax at 802-864-7626, or visit the online SBL Store at www.sbl-site.org. 
David's reach now covers all Israel, then the story would fit nicely prior to David's exploits against Israel's neighbors in 2 Sam 8. After the bloody consolidation of his internal rule-through the systematically serendipitous elimination of his potential rivals for the throne-and the establishment of political contiguity within Canaan, David turns outward to the lands bordering it. ${ }^{69}$ Whether such a schematic bifurcation of political activity conforms to historical reality or not, it offers the historiographer an elegant organizing principle. ${ }^{70}$

On the other hand, the confidence displayed by David, the ease with which he manipulates the Saulide heirs, and the total lack of apparent restraints all argue for distancing the episode as much as possible from the heart of the live struggle between Saul's house and David. ${ }^{71}$ In the previous incidents David plays no role in removing the Saulides, but rather laments and avenges their deaths (2 Sam 1:1-27; 3:28-39; 4:9-12; see also 16:5-1372). The narrator does not state explicitly that David withheld further relations from Michal, but only reports matter-of-factly that "as for Michal daughter of Saul, she did not have children until the day she died" (6:23), perhaps to imply that God had punished her with barrenness. ${ }^{73}$ In the case of the Gibeonites, David personally hands over Saul's children for execution. Furthermore, the Gibeonites formulate their request in the passive, "let them be given over to us," yet David replies in the active voice, which the narrator then amplifies: "The king said, 'I will give them over' ... The king took ... The king handed them over" (21:6b-9a). ${ }^{74}$ The contrast serves to underscore David's direct participation in the destruction of Saul's house-meant here to bring absolution and propitiation. As David's hold on the reins of kingship gets stronger, the narrative appears to indicate, so does

If one accepts the reasoning of Ehrlich, Segal, Haran, and Fokkelman (in this note and the previous one), then the story of the Gibeonites knows and continues another theme in the book of Samuel, the covenant between David and Jonathan. In any case, note the ironic continuities between 2 Sam 21:3-4 and 1 Sam 20:4.

${ }^{69}$ It remains to debate where precisely before 2 Sam 8 the story may have sat, but such deliberations would take us too far afield.

${ }^{70}$ This principle functions in Joshua-Judges too: in Joshua the Israelites engage and defeat the inhabitants of Canaan, so that in Judges enemies primarily come from beyond its borders (Mr. Itamar Kislev, oral communication; on Judges 1-2, see Weinfeld, Promise of the Land, 121-82).

${ }^{71}$ Against Weisman, who, wrongly discounting the sacral side of the story, thinks that David's total and personal control over the situation, without any judicial or administrative institutions, indicates an early period in his reign ("Legal Aspects," 153-54).

72 In 2 Sam 16:12, read probably "my degradation," as in Gen 29:32 and 1 Sam 1:11; see also Gen 31:42; Exod 3:7; 4:31; Deut 26:7; 2 Kgs 14:26; Ps 9:14; 25:18; Lam 1:9; Neh 9:9.

${ }^{73}$ Hertzberg, I \& II Samuel, 281; against Smith, Books of Samuel, 297.

${ }^{74}$ The use of the independent first person pronoun (אני אתן) serves to emphasize David's personal participation as well; see GKC $\$ 135 \mathrm{~d}-\mathrm{h}$; Blau, Grammar, $\$ 70.1$; Waltke and O'Connor, Biblical Hebrew Syntax, \$16.3.2d-e; Joüon-Muraoka, Grammar of Biblical Hebrew, \$146a.

This article was published in JBL 122/1 (2003) 23-52, copyright @ 2003 by the Society of Biblical Literature. To purchase copies of this issue or to subscribe to JBL, please contact SBL Customer Service by phone at 877-725-3334 [toll-free in North America] or 802-864-6185, by fax at 802-864-7626, or visit the online SBL Store at www.sbl-site.org. 
his boldness in dealing with his Saulide adversaries. It would seem, then, from this developmental point of view, that the Gibeonite episode constitutes the final chapter in the struggle against Saul's house, in which David personally and publicly helps silence a final clamor of Saulide voices. ${ }^{75}$

In either case, flat-out contradictions between the Gibeonite story and the related narrative elements in 2 Sam 2:8-9:13 do not exist to preclude its once having actually belonged to that text or a forerunner of it. ${ }^{76}$ By contrast, scholars have overlooked the fact that the story of David's reburial of the royal bones seems to deviate from the other, similar reports in 1 Sam 31:8-13 and 2 Sam 2:4b-7 in several ways, indicating not a once-continuous text rent by the accidents of history and repatched incompletely, but rather an alternative "take," which does not quite serve as a complement. ${ }^{77}$

First of all, the text in 1 Sam 31:1-2 Sam 2:7 seems to have undergone a process of expansion from a story exclusively about Saul's death and remains, to one that in 1 Sam 31:8, 12-13 includes those of his three sons (probably because in 1 Sam 31:1-7 the three fight and fall beside him), and then to one that in 2 Sam 1:4, 5, 12, 17-27 puts the spotlight on Saul and Jonathan (probably under the impact of the addition of David's lament, in 2 Sam 1:17-27). ${ }^{78}$ In

\footnotetext{
${ }^{75}$ But see Stoebe's arguments against interpreting the story in this direction (Das zweite Buch Samuelis, 459-60).

${ }^{76}$ Despite the arguments brought for seeing the story as entirely independent of 2 Sam 9 ,
} Leonhard Rost contrasted 2 Sam 21:1-14, in which David consults with YHWH, knows the whereabouts of Saul's family, and spares Mephibosheth because of an oath to Jonathan, and which emphasizes the centrality of divine will, with 2 Sam 9-20, in which David never consults YHWH, knows nothing of the whereabouts of Saul's family, and spares Mephibosheth for Jonathan without mention of any oath, and which rarely makes divine will an explicit factor (The Succession to the Throne of David [trans. M. D. Rutter and D. M. Gunn; Sheffield: Almond, 1982], 65-66). Alter contended that the loose syntactic style, the weak use of dialogue, the lack of psychological complexity, and the assumption that Saul massacred the Gibeonites all set the story apart from what he calls, "the David story proper" (David Story, 330). Kil noted the absence of the transition, "after that," which introduces other Davidic episodes, in 8:1; 10:1; 13:1; 15:1 (2 Samuel, 500), while, as Fokkelman observed, the phrase that does appear, "during the reign of David" (v. 1), makes the narrator much later than the events narrated (Throne and City, 275; see already Ehrlich, Scripture, 2:246-47), whereas scholars have long felt the close proximity between narrator and narrated in "the David story proper." Indeed, the very emphasis that this story, too, belongs to the time of David signals a later piece; compare Num 15:32; Ruth 1:1; Esth 1:1-2. Surely, if Shimei suspected that David had a hand in the deaths of Ishbosheth, Abner, and even Saul and his sons at Gilboa, it would suffice for him to pronounce David awash in the blood of Saul's house (2 Sam 16:7-8). David's query in 2 Sam 9:1 could have these same losses in mind, and YHWH's oracular designation of Saul as a bloodguilty house in 2 Sam 21:1 could echo Shimei's allegation deliberately to redirect it.

${ }^{77}$ Except for Stoebe, Das zweite Buch Samuelis, 60 n. 51.

${ }^{78}$ On David's lament, see Steven Weitzman, Song and Story in Biblical Narrative: The History of a Literary Convention in Ancient Israel (Bloomington: Indiana University Press, 1997), 133-40. In LXX B its influence extended back into 1 Sam 31:12; the Sahidic version takes this trend even further.

This article was published in JBL 122/1 (2003) 23-52, copyright @ 2003 by the Society of Biblical Literature. To purchase copies of this issue or to subscribe to JBL, please contact SBL Customer Service by phone at 877-725-3334 [toll-free in North America] or 802-864-6185, by fax at 802-864-7626, or visit the online SBL Store at www.sbl-site.org. 
the final result, it appears that, while David focuses in on Saul and Jonathan, the Philistines have absconded with, and the Jabesh-gileadites have returned, the remains of Saul's sons Abinadab and Malkishua as well. The reinterment story in 2 Sam 21:12-13a, 14ao, though, speaks exclusively of Saul and Jonathan, creating the impression that the people of Jabesh-gilead do not have the bones of any other members of the royal family. ${ }^{79}$

Second, and more significantly, the brief episode embedded in 2 Sam 21 appears to suggest that all the while the bones had lain in Jabesh-gilead they had in fact awaited some final treatment. The account in 1 Sam 31:12-13, though, relates that the people of Jabesh-gilead cremated the bodies and buried the remains in what sounds like final rites. Indeed, burial under a tree (1 Sam 31:13; 1 Chr 10:12) would seem to indicate a holy site (as in Gen 35:6-8, also 35:4) — hardly a candidate for exhumation. ${ }^{80}$ Accordingly, both the report David receives and his appraisal of it in 2 Sam 2:4b-5 hint at no expectation of further action regarding the matter, "case closed." 11

Whatever the themes shared among David's reburial of Saul's and Jonathan's remains and the reports in 1 Sam 31:12-13 and 2 Sam 2:4b-5, then, it seems that the reinterment story preserved in 2 Sam 21 diverges from the story of Gibeonite vengeance in that it most likely did not once constitute part

${ }^{79}$ Kirkpatrick harmonized: they "doubtless" buried the bones "of Saul's two other sons who fell at Gilboa, though the historian does not specify them by name" (Books of Samuel, 412).

${ }^{80}$ Radak, ad loc., addresses this double treatment. Rabbinic tradition ( $t$. $\breve{S} a b b .8: 17 ; t$. Sanh. $4: 2-3$; $b$. 'Abod. Zar. 11a) understands this type of funeral pyre as limited to the king's linens. Tg. Jon. renders the verse in this spirit. The text in 1 Chr 10:12 simply skips over it. Several cursive LXX

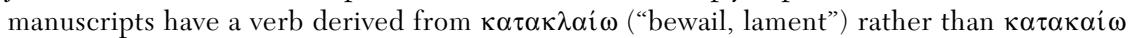
("burn") — a fortuitous error or a deliberate change? McCarter thinks the cremation notice secondary and late, but he offers no explanation for such an anomalous addition (I Samuel: A New Translation with Introduction, Notes, and Commentary [AB 8; Garden City, NY: Doubleday, 1980], 442). If anything, it stands to reason that the burial under the tree represents a pious correction that ended up next to the original it meant to replace. Actually, though, archaeology reveals that cremation often concluded with the burial of some remains; see Elizabeth Bloch-Smith, Judahite Burial Practices and Beliefs About the Dead (Sheffield: JSOT Press, 1992), 52-55. Amos 6:10 may offer another example of Israelite cremation, but see Shalom M. Paul, Amos (Hermeneia; Minneapolis: Fortress, 1991), 214-16. On the significance of burial under a tree, see Bloch-Smith, Judahite Burial Practices, 114-15.

${ }^{81}$ Budde also noted the terminological differences, בעלי (2 Sam 21:9) vs. ישבי (1 Sam 31:11), and בחומת (2 Sam 21:9) (1 Sam 31:10, 12); see Die Bücher Samuel, 309. John Mauchline takes the latter pair to indicate divergent historical traditions as to whether the Philistines hung the corpses in the public square or on the city wall (1 and 2 Samuel [NCB; London: Oliphants, 1971], 303), but Stoebe rightly denies the existence of any contradiction here (Das zweite Buch Samuelis, 455, v. 12 n. c): archaeology has demonstrated that public squares often abutted city walls; see Biblical Archaeology (ed. Shalom M. Paul and William G. Dever; Jerusalem: Keter, 1973), 18; and Amihai Mazar, Archaeology of the Land of the Bible: 10,000-586 B.C.E. (New York: Doubleday, 1990), 469-70.

This article was published in JBL 122/1 (2003) 23-52, copyright $@ 2003$ by the Society of Biblical Literature. To purchase copies of this issue or to subscribe to JBL, please contact SBL Customer Service by phone at 877-725-3334 [toll-free in North America] or 802-864-6185, by fax at 802-864-7626, or visit the online SBL Store at www.sbl-site.org. 
of the running text linking the other preserved reports. ${ }^{82}$ In this case, though, the divergence between the two stories in 2 Sam 21:1-14 does not simply follow along the lines already emerging, as yet another ramification of the sourcecritical division. Because this divergence highlights the two stories as mutually exclusive, it actually confirms the division itself.

To conclude, it appears that an author or scribe-probably the compiler of all the various texts comprising the appendix in 2 Sam 21-24 - came across a story telling how David had the remains of Saul and Jonathan reinterred in the family plot in Benjamin. ${ }^{83}$ The scribe incorporated it into the Gibeonites' story, probably because of their common theme, "the fate of the remains of Saul and his heirs," specifically, the motifs of impalement and reburial. Incorporating this brief account required nothing more elaborate than a simple "cut and paste" method. One might accuse this conflator of sloppiness for having left traces of the editorial work at the seams. It seems more productive, though, to recognize how the results changed the larger, Gibeonite narrative, ultimately creating a new, more finely modulated composition, with a plot illustrating a more complex attitude toward history and causality.

At the psychological level, the current location of the smaller story touchingly suggests that Rizpah's devoted efforts to preserve the bodies moved David so, that he felt compelled to match them by retrieving the bones of Saul and Jonathan from Jabesh-gilead to rebury them in the family plot in Benjamin, along with the bones of those sons given into Gibeonite hands. ${ }^{84}$ Whatever con-

82 This does not necessarily rule out the possibility that it made use of the parallel story; Galen Marquis notes that v. 12 reverses the order of events in 1 Sam 31 (Explicit Literary Allusions in Biblical Historiography [in Hebrew; Ph.D. diss., Hebrew University, Jerusalem, 1999], 171). However, this phenomenon could reflect the poetics of flashbacks rather than scribal techniques for citation.

${ }^{83}$ The story possibly had some relationship with the series of Philistine episodes beginning in 2 Sam 21:15, which would help explain the current order of the text in 2 Sam 21 and the use of "further" in v. 15. In the LXX manuscript tradition, some version of vv. 15b-16a appears right before v. 12 (in one text it appears right before v. 11). For a discussion of this "doublet," see Stephen Pisano, Additions or Omissions in the Books of Samuel (OBO 57; Freiburg: Universitätsverlag; Göttingen: Vandenhoeck \& Ruprecht, 1984), 151-55. For a list of lemmatic correspondences and thematic continuities linking 2 Sam 21:1-14 to ch. 20, see Kil, 2 Samuel, 500 n. 5.

${ }^{84}$ See Ehrlich, Scripture, 2:249-50. The entire analysis by Frolov and Orel takes its cue from this juxtaposition, but their claim that Rizpah "turns the omnipotent king into her obedient tool" goes too far, while they dismiss the interpretation above as "sentimental" and "anachronistic" unconvincingly ("Rizpah on the Rock," 145-46). Fokkelman classically turns up several points of

This article was published in JBL 122/1 (2003) 23-52, copyright $(2003$ by the Society of Biblical Literature. To purchase copies of this issue or to subscribe to JBL, please contact SBL Customer Service by phone at 877-725-3334 [toll-free in North America] or 802-864-6185, by fax at 802-864-7626, or visit the online SBL Store at www.sbl-site.org. 
fidence David evinced in dealing with Saul's descendants Rizpah managed to shake enough to evoke a humane reaction.

At the political level, the inclusion of David's treatment of Saul's and Jonathan's remains effectively mutes his complicity in the deaths of seven of Saul's sons by emphasizing David's love for and dedication to Saul, Jonathan, and "doing the right thing." Saul, the story murmurs, has forced David into this tragic situation; David, for his part, nevertheless continues to pay appropriate respect to Saul and the royal family. The effect humanizes David's control over Saul's family, shifting David's image from that of a cold and too-willing executioner to that of a conflicted ruler, tragically forced to betray his predecessors, but demonstrating an abiding love for them and commitment to their honor. ${ }^{85}$

Plotting the different textual versions of v. 14a along this map, LXX A and Luc "he buried" highlights that, whatever help David had in removing the bodies of the impaled descendants, he insisted on reburying Saul and Jonathan himself. MT "they buried" suggests that David got the Gibeonites to comply with his reburial interests; put more sharply, after having demanded vengeance against the Israelite king who sought to destroy them, they now help bring him to eternal rest. LXX B "the bones of Saul and the bones of Jonathan and of those impaled" completes the integration of the two sources. The Gibeonites, who demanded the grisly death and ignominious exposure of Saul's sons, now join in paying last respects to the entire former royal family.

Finally, at the theological and sacral level, in this combined text, the famine comes as the result of two sins rather than one: the insufficient or improper treatment of Saul and Jonathan's remains as well as Saul's sacrilegious decimation of the Gibeonites. ${ }^{86}$ Correspondingly, God hears the land's entreaty

analogy between the Rizpah pericope and the Philistine-Jabesh-gilead one (Throne and City, 291-92).

85 Typologically, adding the fragmentary story may imply something akin to a lament by David, parallel to others found at pivotal points in the book of Samuel, for Saul and Jonathan in 2 Sam 1:17-27 and for Abner in 2 Sam 3:33-34a.

${ }^{86}$ A midrash in Pirqe R. El., ch. 17, has God charge David with leaving Saul outside the holy land, namely, buried improperly. Another midrash (y. Qid. 4.1, 65c; y. Sanh. 6.9, 23d; b. Yeb. 78b; Midr. Ps. on Ps 17; Midr. Sam., ch. 28; Num. Rab. \$8.4) also splits the apposition between "Saul" and "the House of Bloodguilt" in MT v. 2 into two independent causal clauses by introducing a new explanatory stich (in italics):

"because of Saul"- because he was not eulogized properly;

"and because of the House of Bloodguilt—-because it put Gibeonites to death."

The gloss rounds out the prior asymmetry and resolves the grammatical disagreement between the plural subject "Saul" and "the House of Bloodguilt," and the third singular verb המִית. In effect, rereading the apposition as two separate clauses also softens the contradiction with Deut 24:16, since the original motive clause, rendered as "because it put Gibeonites to death," now refers back not to Saul but to "the house," implying that the entire "house" took part in the aggression. So

This article was published in JBL 122/1 (2003) 23-52, copyright $(\odot 2003$ by the Society of Biblical Literature. To purchase copies of this issue or to subscribe to JBL, please contact SBL Customer Service by phone at 877-725-3334 [toll-free in North America] or 802-864-6185, by fax at 802-864-7626, or visit the online SBL Store at www.sbl-site.org. 
not only because of the absolved violation of the vow and the cleansed bloodguilt but also because of the relocation of Saul and Jonathan. ${ }^{87}$ The effect creates a more ambivalent attitude toward Saul: his sons must die to propitiate the Gibeonites, but God will not relax his own vigil until "YHwH's chosen" with his eight impaled sons—so inevitably infers the LXX—all come to rest in Benjamin.

Such a vital transformation of two independent compositions by their interwoven juxtaposition confirms dramatically for edited pieces of literature, too, the veracity of the dictum, "the whole is greater than the sum of its parts."

indeed suggests Mishnat R. El., 165, lines 20-21; on 166, lines 7-10, the Gibeonites ask for the specific seven who assaulted them.

${ }^{87}$ In the spirit of the midrash (Num. Rab. \$8.4; Pirqe R. El., ch. 17) and Rashi (vv. 1, 14), Fokkelman concludes, "the [plot's] denouement is not possible until the humane policy of David, which bestows recognition and compassion on the whole house of Saul" (Throne and City, 289-90). 